
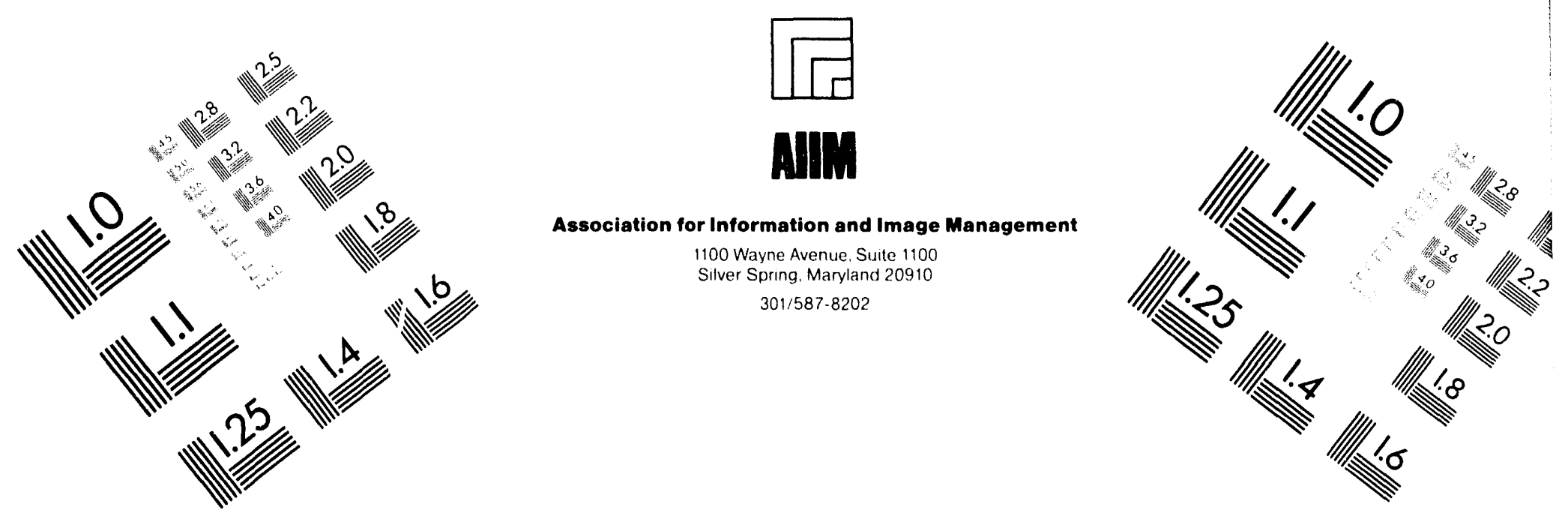

\title{
Centimeter
}

10 Inches
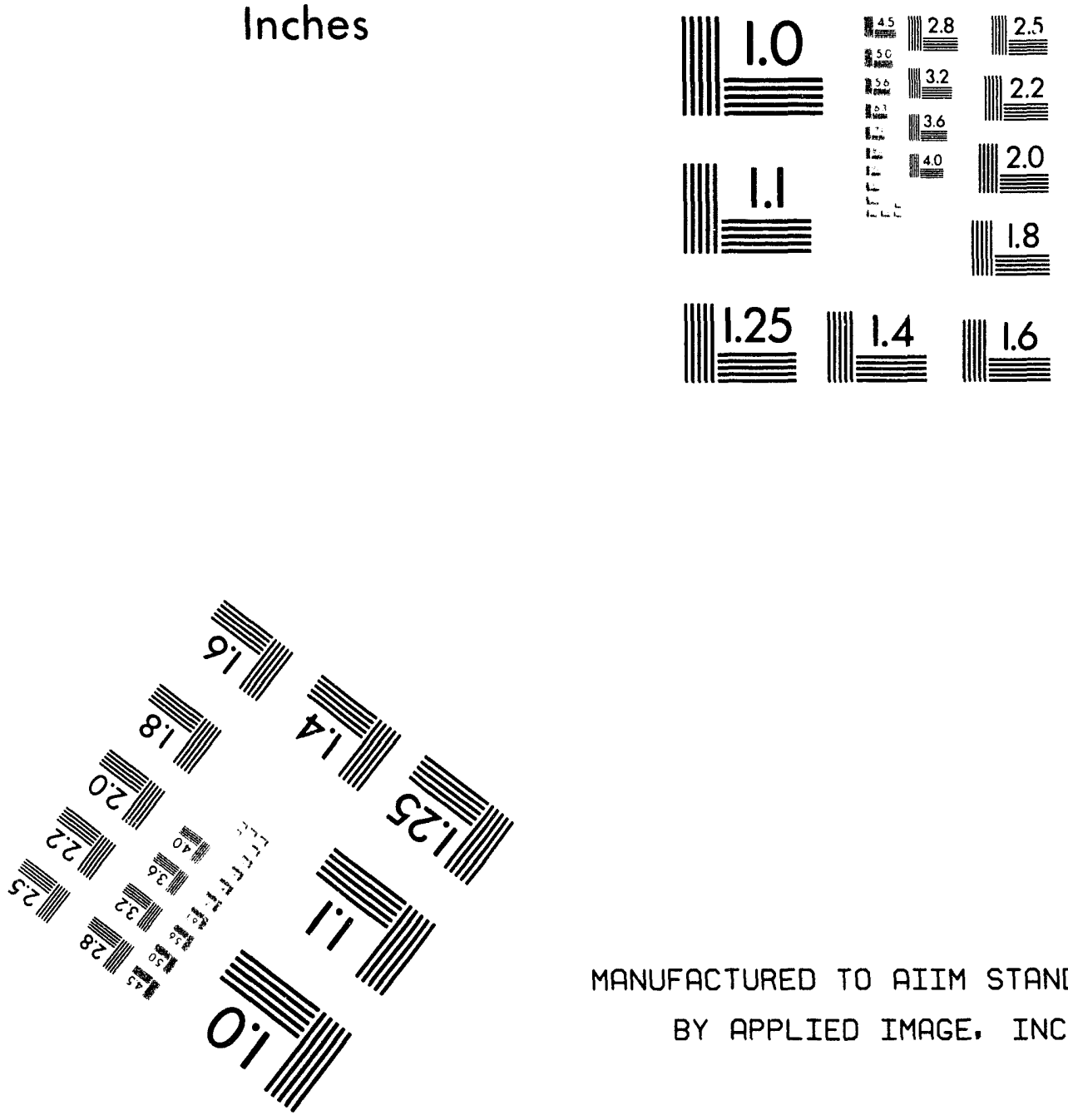

MANUFACTURED TO AIIM STANDARDS

BY APPLIED IMAGE. INC.

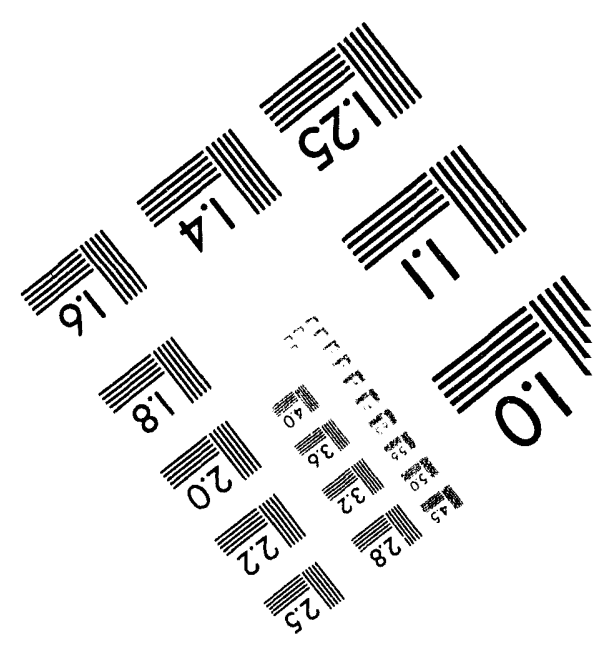



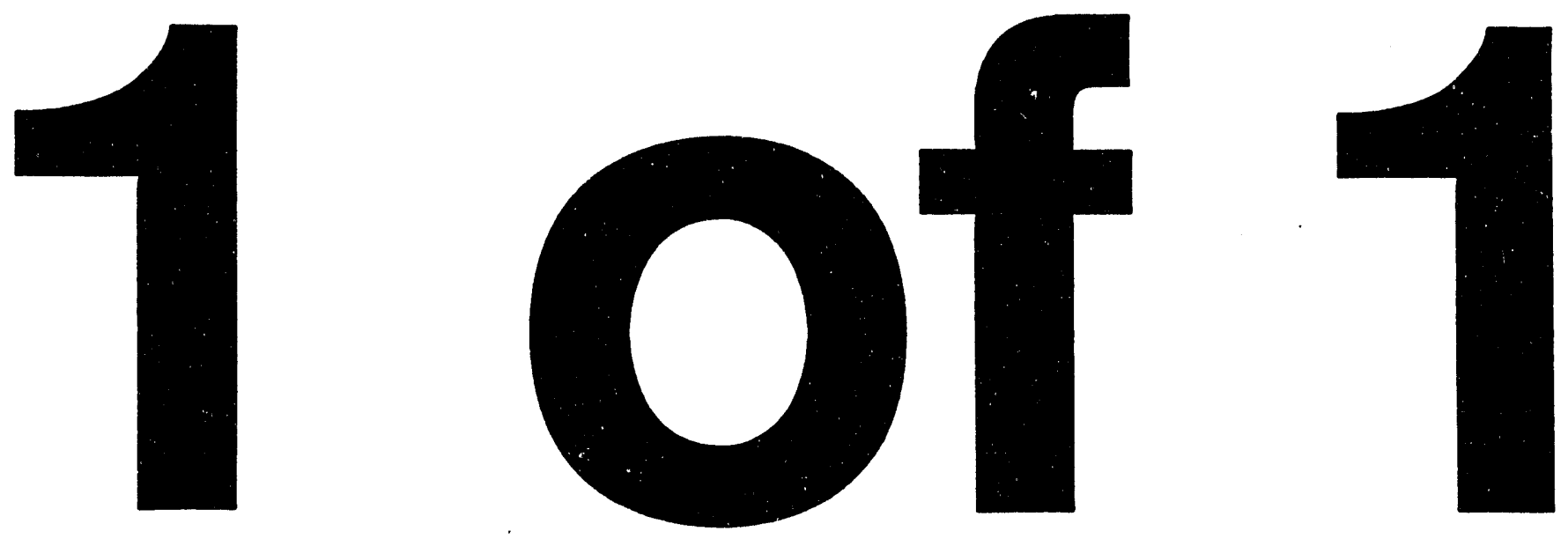
DOE/EA - 0943

\section{ENVIRONMENTAL ASSESSMENT FOR THE DOMESTIC WATER SUPPLY UPGRADES AND CONSOLIDATION ON THE SAVANNAH RIVER SITE}

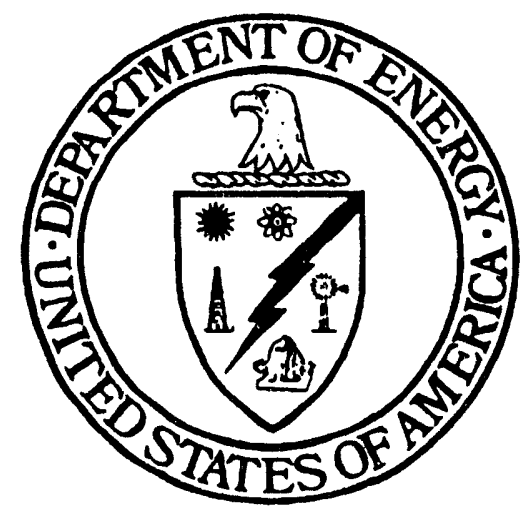

JUNE 1994

UNITED STATES DEPARTMENT OF ENERGY SAVANNAH RIVER OPERATIONS OFFICE SAVANNAH RIVER SITE 


\section{TABLE OF CONTENTS}

INTRODUCTION AND NEED FOR ACTION

2.0 PROPOSED ACTION AND ALTERNATTVES.................................. 1

2.1 Proposed Action ....................................................... 1

2.2 Alternatives to the Proposed Action …....................................... 3

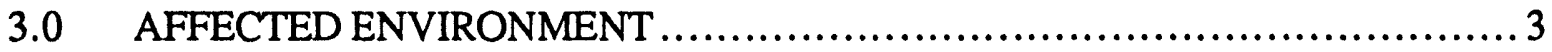

4.0 ENVIRONMENTAL CONSEQUENCES OF THE PROPOSED ACTION ......... 4

4.1 Construction.............................................................. 4

4.2 Operations .......................................................................... 5

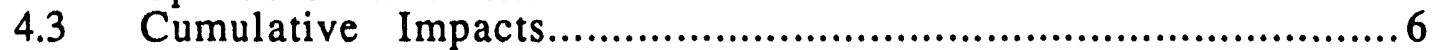

5.0 REGULATORY AND PERMITTING PROVISION CONSIDERATIONS.........7

6.0 LIST OF ORGANIZATIONS CONSULTED ............................. 7

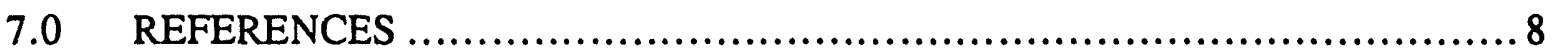

APPENDIXES:

APPENDIX A: Floodplain/Wetlands Assessment

\section{LIST OF FIGURES}

Figure 1. Location of Water Supply Facilities and Distribution Systems

\section{LIST OF TABLES}

Table 1 A and B Area Treatment Facilities Chemical Usage Rates 


\subsection{INTRODUCTION AND NEED FOR ACTION}

The domestic water systems on the Savannah River Site (SRS) are currently in need of upgrading to ensure compliance with the Safe Drinking Water Act and South Carolina Department of Health and Environmental Control (SCDF TEC) Drinking Water Regulations, R61-58.

The SRS has 28 separate groundwater-based drinking water systems in use across the site. These aging systems were designed and constructed in the 1950s and are now facing increasing difficulties in meeting current regulations. Audits of the systems conducted by SCDHEC in 1986, 1988, 1991, and 1993 identified shortfalls in meeting the requirements for secondary maximum containment levels (MCLs) and SCDHEC design standards (Brownlow, 1993). Secondary MCLs are those items, such as odor or appearance, that do not pose a direct health impact. SRS has committed to SCDHEC to correct the drinking water discrepancies and construct two new consolidated inter-area drinking water systems (Spence, 1991, 1993).

Upgrading the SRS drinking water systems would be necessary to support site activities regardless of the makeup or the mission at SRS. As such, the proposed upgrade and consolidation of SRS domestic water systems is treated as part of the "No Action" alternative for the Programmatic Environmental Impact Statement for Reconfiguration of the Nuclear Weapons Complex (DOE, 1991, 1991a).

\subsection{PROPOSED ACTION AND ALTERNATIVES}

\subsection{Proposed Action}

The proposed action is to improve the SRS domestic water facilities and consolidate the existing SRS drinking water systems into two new consolidated systems. The proposed consolidation would combine 10 of the 28 systems to form the two new systems. These upgrade and consolidation activities would include: well modifications to correct deficiencies, chemical treatment facility construction and upgrades, distribution system upgrades, new looped domestic water supply lines (both inter-area and intra-area), new domestic water tie-in-lines, and new elevated water storage tanks. The remaining 18 systems include 17 small systems which are scattered across the site, and the $\mathrm{K}$ Area system. The 17 small systems currently meet all primary MCLs. Since they serve less than 25 people each, SCDHEC regulations for public water systems do not apply and no modifications are required. The K Area system was previously upgraded under the plantwide fire protection project (DOE 199lb).

The proposed consolidation activity would install approximately $38 \mathrm{~km}(24 \mathrm{mi})$ of looped underground piping to connect A, B, C, F, H, N, S, Z and the Savannah River Forest Station (SRFS) drinking water systems into one consolidated loop system (Figure 1). Approximately $2 \mathrm{~km}(1.25 \mathrm{mi})$ of piping would connect the $\mathrm{D}$ and $\mathrm{T}$ Area systems into a single consolidated system. The proposed piping would provide treated water from $D$ to $T$ area, thus eliminating the need to upgrade the storage and chemical treatment systems in T Area. New piping would be installed along existing SRS right-of-ways.

Existing wells in A-Area would be backed up by B-Area wells and supply water to the new consolidated loop system. Existing wells in D-Area would supply water to the smaller consolidated system. Within these new consolidated systems the proposed upgrading actions would install some $14.7 \mathrm{~km}(9.1 \mathrm{mi})$ of distribution piping and some $7.1 \mathrm{~km}(4.4 \mathrm{mi})$ of connecting building tap piping. In addition, upgrades within the area systems in A, B, D, N, T Areas, and the SRFS would include corrosion resistant looped piping, blow-off valves on dead-end mains, isolation flush valves, air relief valves, chemical treatment facility construction and upgrades, and well modifications to correct deficiencies. In A Area, well modifications would consist of installing new piping to route the supply water to the new A Area water treatment facility. The well modifications in the remaining SRS Areas would consist primarily of separating the wells from the domestic water systems and capping the existing domestic water piping. 


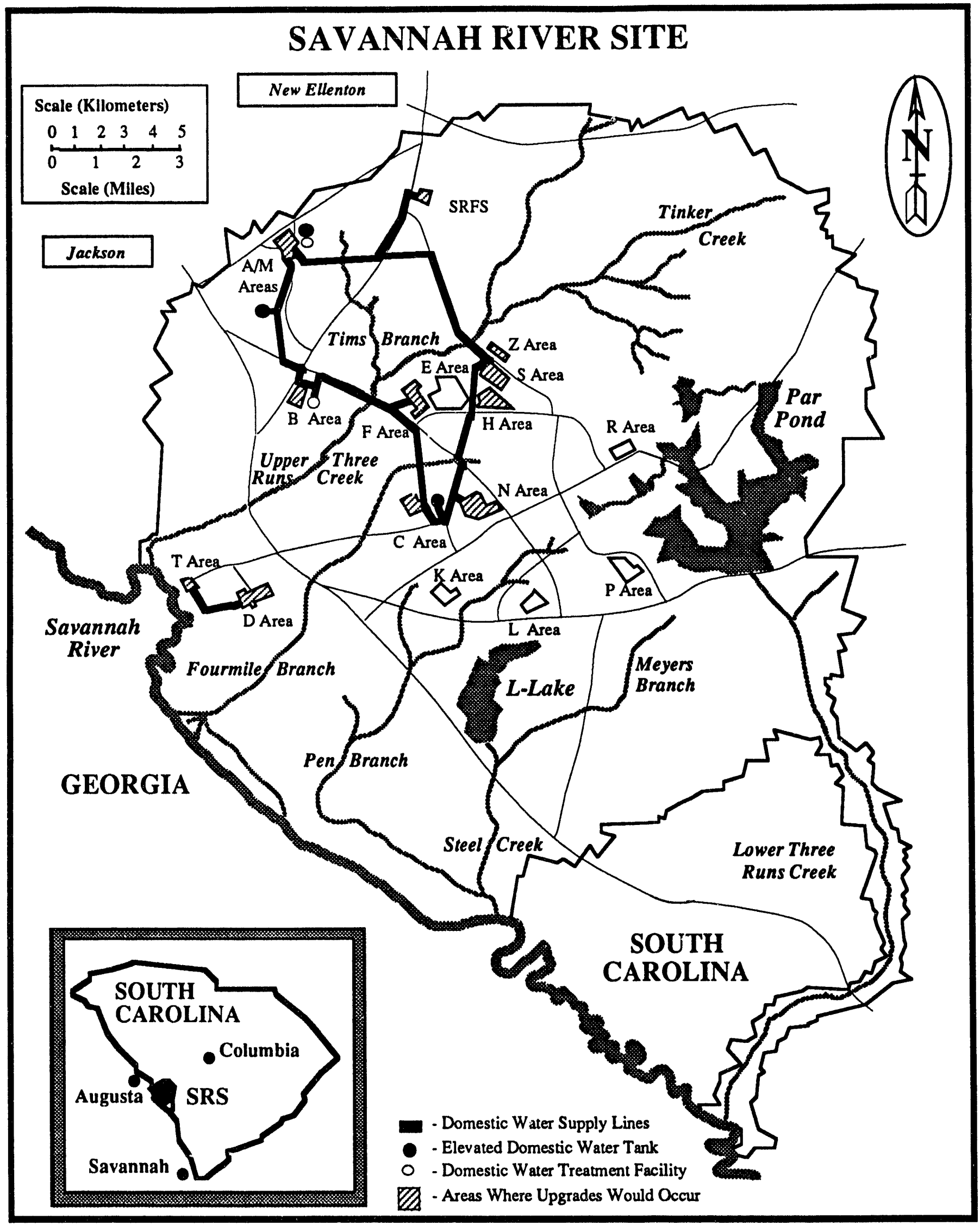

Figure 1. Location of Water Supply Facilities and Distribution Systems 
Two elevated water storage tanks would be installed on the consolidated loop (Figure 1). One 1,892,500liter (500,000-gallon) elevated storage tank would be installed between A and B Areas, and a second 2,460,250-liter (650,000-gallon) elevated storage tank would be installed between $\mathrm{C}$ and $\mathrm{N}$ Areas. An additional 946,250-liter (250,000-gallon) elevated storage tank in A Area would also be utilized.

A new domestic water chemical treatment facility would be constructed in A Area and the treatment facility in B Area would be upgraded to serve as a backup for the A Area plant. The proposed A Area water treatment facility would be capable of providing a maximum flow rate of 0.19 cubic meters per second (cms) $(3,000$ $\mathrm{gpm})$, and the B Area water treatment facility would be upgraded to provide a $0.06 \mathrm{cms}(1,000 \mathrm{gpm})$ flow. Specific upgrades to the B Area treatment facility would include the addition of bulk chemical storage capabilities, booster pumps, flowmeters, HVAC upgrades, and other minor upgrades. Control and monitoring instrumentation would be installed to allow electronic communication among the water treatment facilities, the consolidated loop system, the elevated storage tanks, and the A Area treatment facility.

The proposed action is scheduled to begin detailed design in July of 1994 and construction in March of 1995. Project completion is scheduled by September of 1997.

\subsection{Alternatives to the Proposed Action}

An alternative to the proposed action is to take no action. In accordance with NEPA (40 CFR 1502.14(d)), the "No Action" alternative is included to provide a baseline condition from which to evaluate the potential environmental impacts of the proposed action. This alternative, by definition, would consist of taking no action to upgrade the existing SRS domestic water supply systems and failing to comply with the Safe Drinking Water Act or SCDHEC Regulations.

Another alternative to the proposed action would be the separate upgrade of the individual SRS Area domestic water facilities and systems. This alternative was reviewed and rejected because of the unnecessary expense and unreliability associated with the operation of 28 separate domestic water supply systems (Metcalf \& Eddy, 1993). The operation of 28 separate domestic water systems greatly increases the costs and chances of system failure, mechanical breakdown, and accidental chemical releases to the environment. It also fails to take advantage of economies of scale. It was therefore found to be less favorable than the preferred action.

In addition to the proposed action, 14 alternatives for upgrading and consolidating the domestic water systems on SRS were examined and rejected because of various expense and reliability factors. These alternative recommendations ranged from a single sitewide consolidated domestic water system that serviced all operational areas, guard posts, and pump houses to a segmented partially looped domestic water supply system that would tie in with the adjacent town of Jackson, South Carolina (Metcalf \& Eddy, 1993). The majority of these alternatives were rejected because they called for unnecessarily upgrading many of the 17 smaller domestic water systems referenced in section 2.1. The remainder of the alternatives were dismissed because of elevated operational and construction costs and increased environmental impacts to the SRS.

\subsection{AFFECTED ENVIRONMENT}

The SRS encompasses approximately 199,000 acres in southwestern South Carolina approximately 25 miles southeast of Augusta, GA. SRS contains five nuclear production reactor areas; two chemical separations areas; waste processing, storage, and disposal facilities; and various supporting facilities. More than 21,000 people work at SRS in the various operating areas and would be served by the new systems and upgraded facilities. A comprehensive discussion of SRS and associated environs is presented in the Reactor Operation Environmental Impact Statement (DOE, 1990), and in the Reactor Operation Environmental Information Documents, Volumes I-III (WSRC, 1989a, b, and c). The most recent socioeconomic survey of the six-county SRS area of influence contains additional information (NUS, 1992). 


\subsection{ENVIRONMENTAL CONSEQUENCES OF THE PROPOSED ACTION}

\subsection{Construction}

The proposed upgrades and consolidation of the SRS domestic water supply systems would occur within the fenced confines of previously developed and existing SRS operational areas, and within the right-of-way of existing SRS roadways, steam lines, and power lines. Figure 1 shows the Areas on SRS slated for domestic water upgrades and the proposed route for the domestic water consolidation pipeline. The proposed action would include the clearing of a small number of selected trees to minimize routing through floodplain and wetlands areas. Other than the temporary disturbance associated with construction, the long term impact of this timber clearing would result in the replacement of about 0.6 total acres of loblolly pine and bottomland hardwoods with grass and briars.

Construction impacts would be minimized through use of sedimentation and erosion control measures. Operation of construction equipment in wetlands and floodplain areas would be minimized. Silt fences and other erosion control structures as needed would be installed to ensure there is no deposition in down slope wetland areas. Long-term construction impacts in the floodplain and wetland areas would be minimized through the removal of excess excavated sidefill and restoration to the original contours following completion of construction. The wetland soils would require the use of platform support mats in order to install the support pillars that would anchor the line over the streams and floodplain. The mats would be removed when the line is completed. An erosion control plan would be developed to comply with applicable State and local floodplain protection standards. Additionally, those standards outlined by the South Carolina Wildlife and Marine Resources Department (Timmerman, 1994) to protect the floodplain/wetlands and biotics characteristics of the proposed project area would be followed to ensure that no additional impacts would occur. Best management practices would be employed during construction and maintenance activities associated with this proposed action.

Domestic water system upgrades would result in some soil disturbance as trenches are excavated to lay new pipe. The minimization and mitigation of this potential source of sedimentary pollution would be documented under a pollution prevention plan meeting South Carolina Land Resources Commission (SCLRC) and SCDHEC requirements. Typical methods employed at SRS to minimize and mitigate potential erosion sources include: the use of silt fences to prevent transport of sediment; the seeding of soil stockpiles to prevent erosion; and the development of siltation basins to trap sediments in construction site runoff.

A Floodplain/Wetlands Assessment (Appendix A) was prepared in compliance with 10 CFR Part 1022 for those areas encompassed by the proposed pipelines. This Floodplain/Wetlands Assessment determined that wetlands did exist along the proposed pipeline route and delineated the best possible routes to minimize impact on the floodplain/wetlands at SRS. The Floodplain/Wetlands Assessment stated that the project could be expected to cause a temporary increase in the sediment load levels of impacted SRS streams less than that experienced due to a rain storm.

The proposed domestic water upgrades would result in the generation of some construction related debris. This debris composed primarily of soil and rubble would be disposed of in the SRS sanitary landfill or an erosion control pit.

Any contaminated soil generated during construction would be disposed of onsite in waste disposal areas in accordance with applicable regulations and site procedures. Any soils contaminated with hazardous materials would be handled and disposed of in accordance with Resource Conservation and Recovery Act (RCRA) regulations. Normal construction and operation of the proposed domestic water facilities would not involve radioactive materials.

When viewed in light of the present SRS employment of about 21,000 workers, the socioeconomic effect of a construction workforce of 100 workers, is negligible. The proposed action was examined for any potential transportation impacts on air quality, traffic load, or traffic flow and no impacts are expected. 
Cultural resources at SRS are managed under the terms of a Programmatic Memorandum of Agreement (PMOA) among DOE, the South Carolina State Historic Preservation Officer (SHPO), and the Advisory Council on Historic Preservation (DOE, 1990a). DOE uses this PMOA to identify cultural resources, assess these in terms of National Register eligibility, and develop mitigation plans for affected resources in consultation with the SHPO. DOE would comply with the stipulations of the PMOA for all activities related to the construction and operation of the proposed domestic water supply upgrades.

It is highly unlikely that any aspect of the proposed project would affect SRS archeological resources as all project actions would occur within the fenced confines of previously developed and operational industrial areas, and along the right-of-way of existing SRS roadways, steam lines, and powerlines. To ensure that no resources are infringed upon, a survey of the prospective sites was conducted by the University of South Carolina Department of Archaeology and Anthropology as part of the routine SRS site use permit system.

The management and utilization of SRS forests, soils, watersheds, and wildlife are described in the SRS Natural Resources Management Plan (DOE, 1991c) and defined under the terms of a Memorandum Of Agreement (MOA) between DOE, the SRFS, the Soil Conservation Service (SCS), and the Westinghouse Savannah River Company (WSRC). DOE uses this MOA to define the roles and responsibilities of the various agencies and organizations in the management of natural resources on SRS.

It is also highly unlikely that any aspect of the proposed project would affect SRS biotic resources as all project actions would occur within the fenced confines of previously developed and operational industrial areas, and along the right-of-way of existing SRS roadways, steam lines, and powerlines. To ensure that no resources are infringed upon, a survey was conducted by the Savannah River Forest Station (SRFS) as part of the routine SRS site use permit system. The location of the proposed action was assessed under a biological assessment for threatened and endangered species and under a biological evaluation which reviewed sensitive species (Hyatt, 1994 \& 1994a). These evaluations addressed the potential effects of the proposed action on threatened, endangered, and sensitive plant and animal species. No effect on any federally or state listed protected species would be expected as a result of the proposed action. This determination of no impact on threatened, endangered, and sensitive species was concurred with by the U.S. Fish and Wildlife Service after reviewing the SRFS reports (Banks, 1994).

\subsection{Operations}

Once completed, the proposed facilities would be operated with a staff of properly trained and certified personnel. These personnel are currently employed by SRS. Thus, there would be no socioeconomic impact associated with normal operations.

The proposed action calls for existing wells and pumps in A Area to supply the domestic water from the lower water-bearing Cretaceous sediments (Middendorf Aquifer) for use throughout the consolidated system. The increased usage of the A Area wells does not represent a real increase in usage of the Middendorf Aquifer. Under normal circumstances, as the usage rate of the A Area wells increase, there would be an reciprocal decrease in water usage rates by the wells located in the Areas to be supported by the consolidated systems.

The project would install a $30 \mathrm{~kW}$ back-up diesel-driven generator at the proposed A Area water treatment facility to provide power in the event of an outage or required maintenance. Prior to operation, this dieseldriven generator would be required to undergo review by SCDHEC. If it operates less than 250 hours per year, a permit would not be required. The existing domestic water diesel-driven generators which are in place across the SRS in the individual operational areas would remain in place to support the area fire water systems. These diesel generators are permitted for operation through SCDHEC.

Sodium hypochlorite $(\mathrm{NaOCl})$, liquid zinc orthophosphate $\left(\mathrm{PO}_{4}\right)$, and soda ash/carbonate $\left(\mathrm{Na}_{2} \mathrm{CO}_{3}\right)$ would be stored at the domestic water treatment facilities in A and B Areas. These chemicals would be used to chemically treat groundwater so that the $\mathrm{pH}$, clarity, and MCLs all meet SCDHEC Drinking Water Regulations. The anticipated annual usage rates of these chemicals at the A and B Area treatment facilities are listed in Table 1. The chemicals discussed above are presently being stored and used at comparable 
amounts and rates across the SRS at the various individual domestic water treatment facilities. The proposed action would serve to consolidate their storage at the two proposed treatment facilities.

Past history has shown no worker impacts resulting from use of these chemicals. The workers employed at the treatment facilities would be trained in accordance with OSHA Standards for the proper handling and precautionary measures to be taken when working with the chemicals listed above. Workers would be required to wear the protective clothing and equipment appropriate for the materials at hand (WSRC, 1993).

Table 1

A and B Area Treatment Facilities Chemical Usage Rates

\begin{tabular}{cc}
\hline Chemical & Annual Usage Rate \\
\hline sodium hypochlorite & 27,745 liters $(7,330 \mathrm{gal})$ \\
zinc orthophosphate & 26,359 liters $(6,964 \mathrm{gal})$ \\
soda ash/carbonate & 66,498 kilograms $(146,600 \mathrm{lbs})$ \\
\hline
\end{tabular}

A 30 day chemical supply of 2,271 liters (600 gal) of sodium hypochlorite; 2,157 liters (570 gal) of zinc orthophosphate; and 5,443 kilograms (12,000 lbs) of soda ash/carbonate would be stored at the A Area treatment facility. Accidental liquid releases from the chemical storage tanks would be prevented from reaching the environment by curbs and dikes designed to contain such spills. Workers could suffer irritation to respiratory passages, including coughing or inhalation difficulties, from such spills. Ventilation would be provided in the facilities to keep fumes from such spills to a minimum. Respiratory equipment, eyewash fountains, and safety showers would be located in the facilities, in conformance with safety regulations. The facilities would also be equipped with high/low level alarms, sump pumps, and overflow alarms to minimize the effects of an accidental spill.

\subsection{Cumulative Impacts}

The principal cumulative impact of the proposed project would be the potential for erosion/sediment transport into SRS streams and waterways. However, this potential pollutant source would be minimized by following an approved pollution prevention plan that meets all SCLRC and SCDHEC requirements prior to beginning any construction activity.

There would be no adverse impact on the local groundwater levels from the increased usage of the A Area wells for the consolidated system. In past operations, these wells have supplied groundwater at rates in excess of those which would be required by the proposed action (Calloway, 1987, 1988; Wise, 1989). The projected usage of these wells to supply the consolidated domestic water supply system would not adversely impact the aquifer (Price, 1993). All existing SRS wells have check valves in place for backflow prevention in accordance with SCDHEC regulations.

No plans exist for any SRS wells to be abandoned. The SRFS and N Areas wells would remain in service to provide fire water. The wells in $\mathrm{F}, \mathrm{H}, \mathrm{S}$, and $\mathrm{T}$ Areas would remain in service to provide a combination of fire water, service water, and process water. The D Area wells would continue to provide domestic water for $\mathrm{D}$ and $\mathrm{T}$ Areas. Z Area currently has no wells and is provided with water from $S$ Area wells. The B Area wells would remain in service to provide firewater and to serve as a backup to the A Area domestic water treatment facility. In C Area the area piping and upgrades would be installed under the plantwide fire protection project under separate National Environmental Policy Act (NEPA) documentation (DOE, 1991b).

No adverse impacts are expected from the increased levels of stored chemicals in the A and B Area treatment facilities based on past SRS history These facilities would be designed and constructed with standard protective measures necessary to prevent accidental spills from reaching the surrounding environment (i.e., curbs and dikes, sump pumps, over flow alarms, etc.). These chemicals are currently in use at individual area domestic water treatment facilities across SRS and their consolidation would serve to tighten the control and accountability over these chemicals. 


\subsection{REGULATORY AND PERMITTING PROVISION CONSIDERATIONS}

DOE policy is to perform its operations in compliance with all existing applicable federal, state, and local laws and regulations and with all DOE orders. This section discusses the major regulatory permit programs that might be applicable to the proposed action.

This EA was prepared to comply with National Environmental Policy Act (NEPA); the Council on Environmental Quality Regulations on Implementing NEPA (40 CFR Parts 1500-1508); DOE National Environmental Policy Act; Implementing Procedures and Guidelines Revocation, Final Rule and Notice (10 CFR Part 1021); and DOE Order 5440.1E.

The Floodplain/Wetlands Assessment was prepared in accordance with DOE Regulations for Compliance with Floodplain/Wetlands Environmental Review Requirements (10 CFR Part 1022), which implement the procedural provisions of Executive Order 11988, Floodplain Management, and Executive Order 11990, Protection of Wetlands.

Disposal of any hazardous or mixed waste (low-level radioactive hazardous waste) would comply with RCRA requirements and the South Carolina Hazardous Waste Management Regulations (SCHWMR) R.6179.

All domestic water system upgrades and improvements would require a public water works construction and operating permits from the State of South Carolina and are required to meet SCDHEC Primary Drinking Water Regulations, R61-58.

As necessary, Army Corps of Engineers Permits (Section 404) would be obtained for stream crossings or any construction activity in the Floodplain/Wetlands. It is probable that the Corps would qualify the project under an approved nationwide permit based on the findings in the Floodplain/Wetlands Assessment. Any permit applications would be filed and granted prior to initiating any construction activity.

A permit from the South Carolina Budget and Control Board (Regulation 19-450) would be obtained for crossing navigable streams. This permit would be required for both crossings (Road C and Road F) of Upper Three Runs Creek.

South Carolina Land Resource Commission Regulations 72-300 (which establishes the procedures and minimal standards for all land disturbing activities) and SCDHEC/National Pollutant Discharge Elimination System (NPDES) General Permit SCR 100000 (which authorizes storm water discharges associated with industrial activity that would result in the disturbance of five or more acres of total land area) would regulate project erosion control activity and must be followed with respect to the implementation of the proposed pollution prevention plan.

All operational permits (i.e., SCDHEC Air Quality; WSRC Power Services Utilization, Parts B and C; SCDHEC Domestic Water Tie-In) would be required prior to operational start up of the proposed action.

\subsection{LIST OF ORGANIZATIONS CONSULTED}

This document was compiled in part from information contained in the Reactor Operation Environmental Impact Statement (DOE, 1990). Information was provided by, discussed with, and/or reviewed by personnel in the following organizations;

- U. S. Department of Interior, Fish and Wildlife Service, Charleston Office

- U. S. Department of Agriculture, Forest Service, Savannah River Forest Station

- University of South Carolina, Department of Archaeology and Anthropology 


\subsection{REFERENCES}

Banks, R. L., 1994. Memorandum to P. K. Stone, May 24, 1993, re: Upgrade and Consolidation of the Domestic Water Supply Savannah River Site, FWS Log No. 4-6-94-282, United States Department of the Interior, Fish and Wildlife Service, Charleston, South Carolina.

Brownlow, J. J., 1993. Memorandum to W. D. Dunaway, June 14, 1993, re: Sanitary Survey of 11 Domestic Water Supply Systems, South Carolina Department of Health and Environmental Control (SCDHEC), Columbia, South Carolina.

Calloway, M. K. \& Turner, R. D., 1987. Memorandum to W. B. Holt, July 20, 1987, re: Performance Test Results of Well 905-113G, Westinghouse Savannah River Company, Savannah River Site, Aiken, South Carolina.

Calloway, M. K., 1988. Memorandum to W. B. Holt, February 9, 1988, re: Performance Testing of Well 905-82A, Westinghouse Savannah River Company, Savannah River Site, Aiken, South Carolina.

DOE (U. S. Department of Energy), 1990. Final Environmental Impact Statement, Continued Operation of K-, L-, and P-Reactors, Savannah River Site, DOE/EIS-0147, Savannah River Operations Office, Aiken, South Carolina.

DOE (U.S. Department of Energy), 1990a. Programmatic Memorandum of Agreement Among Savannah River Operations Office, U.S. Department of Energy, The South Carolina State Historic Preservation Officer, and the Advisory Council on Historic Preservation Concerning the Management of Archaeological sites on the Savannah River Site, Aiken, Allendale and Barnwell Counties, South Carolina. August 24, 1990. Savannah River Operations Office, Aiken, South Carolina.

DOE (U. S. Department of Energy), 1991. Nuclear Weapons Complex Reconfiguration Study. DOE Defense Programs 0083, U. S. Department of Energy, Washington, DC.

DOE (U. S. Department of Energy), 1991a. Intent to Prepare Programmatic Environmental Impact Statement for Reconfiguration of the Nuclear Weapons Complex, Federal Register 56 FR 5590-5596.

DOE (U. S. Department of Energy), 1991b. Environmental Assessment for the Installation and Operation of the Plantwide Fire Protection Systems and Related Domestic Water Supply Systems, DOE/EA-0476, Savannah River Field Office, Aiken, South Carolina.

DOE (U. S. Department of Energy), 1991c. Natural Resources Management Plan: Strategic Guidance for the Savannah River Site's Natural Resources Programs, Savannah River Field Office, Aiken, South Carolina.

Hyatt, P. E., 1994. Biological Assessment for Threatened and Endangered Species, April 26, 1994, United States Department of Agriculture, Forest Service, Southern Region, Savannah River Forest Station, Aiken, South Carolina.

Hyatt, P. E., 1994a. Biological Evaluation for Sensitive Species, April 26, 1994, United States Department of Agriculture, Forest Service, Southern Region, Savannah River Forest Station, Aiken, South Carolina.

Metcalf \& Eddy, Inc., 1993. Domestic Water Consolidation Study, JAMIS\# 010225, February 1, 1993, Savannah River Site, Aiken, South Carolina.

NUS (NUS Corporation), 1992. Socioeconomic Characteristics of Selected Counties and Communities Adjacent to the Savannah River Site, NUS Report No. 5234, Savannah River Center, Aiken, South Carolina. 
Price, V., 1993. Memorandum to S. C. Kozemko, November 12, 1993, re: Ground Water Supply in A/M Area of SRS, Westinghouse Savannah River Company, Aiken, South Carolina.

Spence, D. R., 1991. Memorandum to E. H. Jenings, October 21, 1991, re: Letter of Commitment on the Savannah River Site (SRS) Domestic Water Systems, Savannah River Operations Office, Aiken, South Carolina.

Spence, D. R., 1993. Memorandum to J. L. Rucker, May 21, 1993, re: Consolidation of Domestic Water Systems at SRS, Savannah River Operations Office, Aiken, South Carolina.

Timmerman, J. A., 1994. Memorandum to R. Grizzle, May 12, 1994, re: P/N EIS-9404-009 - Department of Energy, Aiken/Barnwell County, South Carolina Wildlife and Marine Resources Department, Columbia, South Carolina.

Wise, R. S., 1989. Memorandum to H. R. Main \& J. T. Holland, March 17, 1989, re: Well 905-112G Sand Pumpage and Performance Test Results, Westinghouse Savannah River Company, Savannah River Site, Aiken, South Carolina.

WSRC (Westinghouse Savannah River Company), 1989a. Reactor Operation Environmental Information Document, Volume I: Geology, Seismology and Subsurface Hydrology (U). WSRC-89-815 Savannah River Site, Aiken, South Carolina.

WSRC (Westinghouse Savannah River Company), 1989b. Reactor Operation Environmental Information Document, Volume II: Ecology (U), WSRC-89-816 Savannah River Site, Aiken, South Carolina.

WSRC (Westinghouse Savannah River Company), 1989c. Reactor Operation Environmental Information Document, Volume III: Meteorology, Surface Hydrology, Transport and Impacts (U), WSRC-89-817, Savannah River Site, Aiken, South Carolina.

WSRC (Westinghouse Savannah River Company), 1993. Industrial Hygiene, Procedure Manual 4Q, Savannah River Site, Aiken, South Carolina. 
APPENDIX A: Floodplain/Wetlands Assessment 


\author{
Floodplain/Wetlands Assessment \\ for the \\ Domestic Water Supply Upgrades and Consolidation \\ on the \\ Savannah River Site
}

\title{
1.0 DESCRIPTION OF PROJECT
}

This Floodplain/Wetlands Assessment is prepared in compliance with 10 CFR Part 1022 as an Appendix to the Environmental Assessment for the Domestic Water Supply Upgrades and Consolidation on the Savannah River Site. The proposed project activities would involve domestic water supply pipelines crossing of floodplain/wetlands along the route of the proposed pipeline. These impacted areas would include:

- A domestic water supply pipeline crossing of the Savannah River Site (SRS) stream Upper Three Runs Creek at two separate locations in the vicinity of Road C and Road F.

- A domestic water supply pipeline crossing of the SRS stream Fourmile Branch at two separate locations in the vicinity of Road 4 and Road C-4.

- A domestic water supply pipeline crossing of the SRS stream Tims Branch in the vicinity of a $115 \mathrm{KV}$ Electrical Power Transmission Line intersection.

\subsection{EFFECT ON FLOODPLAIN OR WETLANDS}

\subsection{Floodplain/Wetlands - Upper Three Runs Creek Crossing at Roads C and F}

The domestic water pipeline is planned to run along a field road about 120 to 240 meters $(\mathrm{m})(400$ to $800 \mathrm{ft}$ ) south southwest of SRS Road C (Figure A-1). This route will cross about $914 \mathrm{~m}(3,000 \mathrm{ft})$ of floodplain and about $91 \mathrm{~m}$ ( $300 \mathrm{ft}$ ) of wetlands. The pipeline is to be buried along the field road right-of-way to the point where the road ends about $183 \mathrm{~m}$ (600 ft) west of the Upper Three Runs channel. At this point the pipeline will be placed on piles and pillars to cross about $91 \mathrm{~m}$ (300 ft) of wetlands and floodplain and the stream. The pipeline would "bridge" the stream channel and cross the stream aboveground with the pipeline suspended above the stream by pillars located on either side of the stream channel. Construction impacts would be minimized through the use of portable platform mats to support workers and equipment. Excess excavated soils would be removed. After crossing the stream channel the pipeline will then be placed on piles and continue on to intersect with SRS Road C. The erosion control plan will be carefully followed to avoid sediments moving into the wetlands as a result of construction along this route. The approximate acreage of wetlands to be impacted is 0.3 acres and the floodplain area is less than 2.0 acres. There should be no loss of wetlands associated with the pipeline crossing at this location and impact is expected to be minor. No clearing of trees would be needed if the pipeline is routed along the road bed of the abandoned roadway. At the end of the road a route would be selected that would avoid the loss of bottomland hardwood by cutting a small amount of local sweetgum growth. To minimize the potential for impact to the wetlands if the trees are cut and the stumps would be left in the ground.

The domestic water pipeline is planned to run along the shoulder of Road F (Figure A-2). At Upper Three

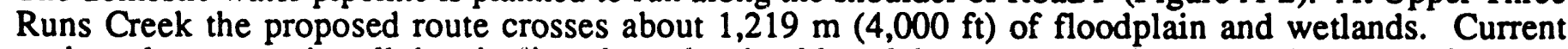
project plans are to install the pipciine along the shoulder of the road about 4 to $8 \mathrm{~m}$ (12 to $25 \mathrm{ft}$ ) from the asphalt surface. Along the side of Road F at the base of the steep slope, there are wetlands in most places; however, placing the pipeline on the shoulder would avoid any impact to the wetlands. At about $99 \mathrm{~m} \mathrm{(325}$ ft) northwest from the bridge the pipeline would turn away from the road and down into the floodplain and then run parallel to the road at about $21 \mathrm{~m}(70 \mathrm{ft})$ west of the bridge. The pipeline would be suspended above ground on pillars during this section of the route. This area has had sufficient fill added during road 
and bridge construction to change the hydrology to one of non-wetland. The overstory vegetation in this area consists of 30 year old loblolly pine. The pipeline would "bridge" the stream channel and cross the stream aboveground with the pipeline suspended above the stream by pillars located on either side of the stream channel. Once across the stream the pipeline would then angle back up to the shoulder of Road $F$ some $99 \mathrm{~m}$ ( $325 \mathrm{ft}$ ) southeast of the bridge. Impact to the area would consist of clearing of an approximately $6 \mathrm{~m}(20 \mathrm{ft}$ ) right-of-way through the 30 year old loblolly pine within the 100 year floodplain (a DOE set aside area). Two or three pillars would be placed in the stream to support the pipeline. Long term impact on the floodplain would be the replacessent of about 0.3 acres of loblolly pine with grass and briars. Sediment from installation of the pillars in the stream channel could cause a short term impact to aquatic studies down stream. This impact would be very minor compared to the regular sediment load of Upper Three Runs Creek resulting from a rain storm, and should not last more than a few days following completion of the work. It is possible that the pipeline could be attached to the bridge and not impact the setaside area, but this is still pending a decision on whether or not the bridge would be replaced.

\subsection{Floodplain/Wetlands -Tims Branch Crossing Along $115 \mathrm{KV}$ Line}

Plans are for the pipeline to run from A Area along Steed Pond Road, and other right-of-ways, until it intersects with the right-of-way for a $115 \mathrm{KV}$ electrical power transmission line (Figure A-3). From this point the pipeline would travel down the right-of-way which is maintained on either side of the power lines until it intersected with SRS Road 2. The pipeline would "bridge" the strean channel and cross the stream aboveground with the pipeline suspended above the stream by pillars located on either side of the stream

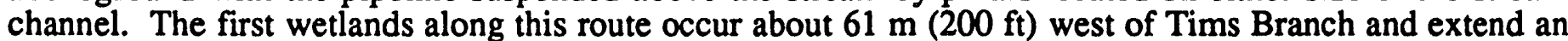

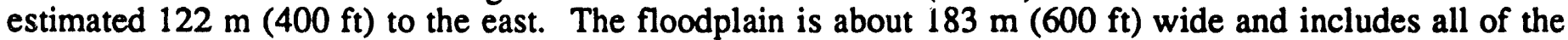
wetlands. If the pipeline can be constructed upon the right-of-way there should be no long term impact to the wetlands.

\subsection{Floodplain/Wetlands - Fourmile Branch Crossing Roads 4 and C.4}

The pipeline would travel south from $H$ Area along the side of SRS Road 4, within $9 \mathrm{~m} \mathrm{(30} \mathrm{ft)} \mathrm{of} \mathrm{the} \mathrm{asphalt}$ surface, where it would cross Fourmile Branch and continue on to SRS Road C (Figure A-4). The route would cross about $30 \mathrm{~m}$ (100 ft) of wetlands at the channel. The pipeline would likely be placed on pillars rather than attached to the bridge. The pipeline would "bridge" the stream channel and cross the stream aboveground with the pipeline suspended above the stream by pillars located on either side of the stream channel. Wetland impact would involve the installation of two pillars in the wetlands. Removal of a small amount of trees along the $30 \mathrm{~m}(100 \mathrm{ft})$ of the route through the wetlands would be required. Impact to the wetlands and the floodplain is considered short term.

Coming from C Area the pipeline would travel along the utilities right-of-way (SRS Road C-4) where it would cross Fourmile Branch and continue on to F Area (Figure A-4). The pipeline would "bridge" the stream channel and cross the stream aboveground with the pipeline suspended above the stream by pillars located on either side of the stream channel. No wetlands impact is anticipated. The pipeline would travel $91 \mathrm{~m}(300 \mathrm{ft})$ through the floodplain, but is expected to cause only short term impact in this area.

\subsection{ALTERNATIVES CONSIDERED}

Alternatives to the proposed action are covered in Section 2 in the Environmental Assessment for the Domestic Water Supply Upgrades and Consolidation on the Savannah River Site. One of the alternative actions covered in the EA included upgrading the individual area domestic water facilities, thus eliminating the need for consolidation piping. This alternative was not considered favorable due to cost and reliability concerns. In addition to the proposed action, 14 alternative methods for upgrading and consolidating the domestic water systems on SRS were examined and rejected because of various expense and reliability factors. 


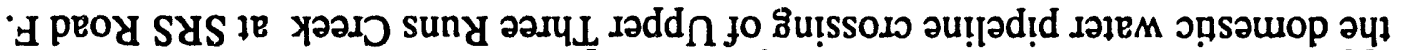

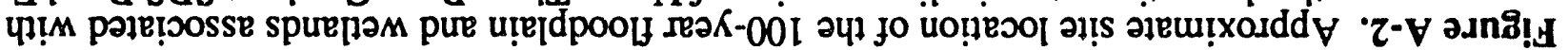

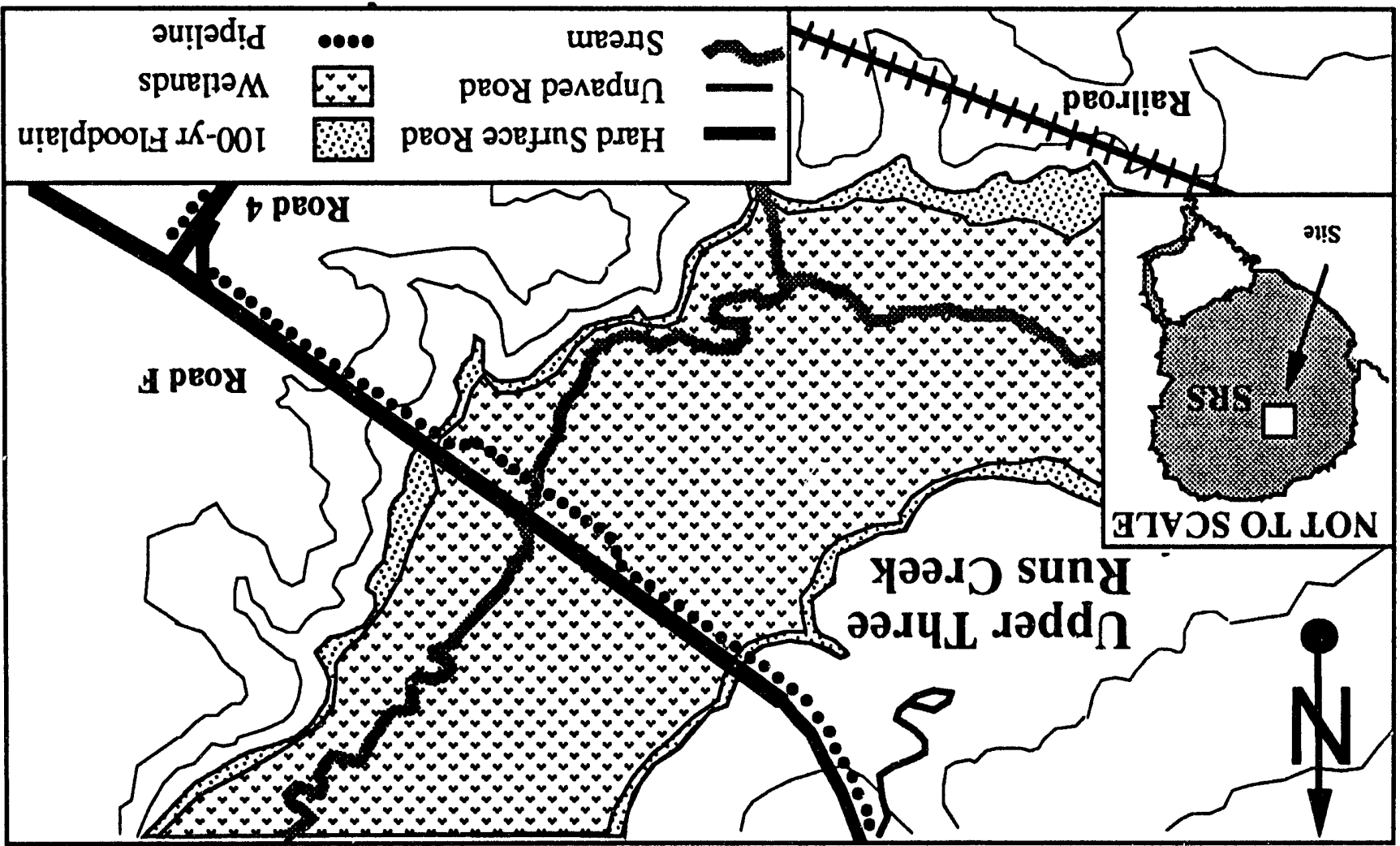

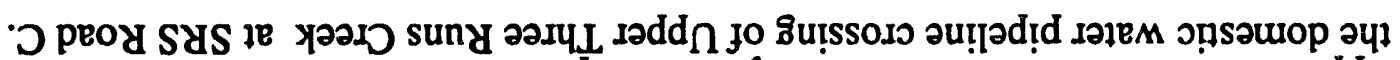

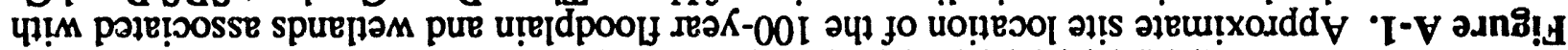

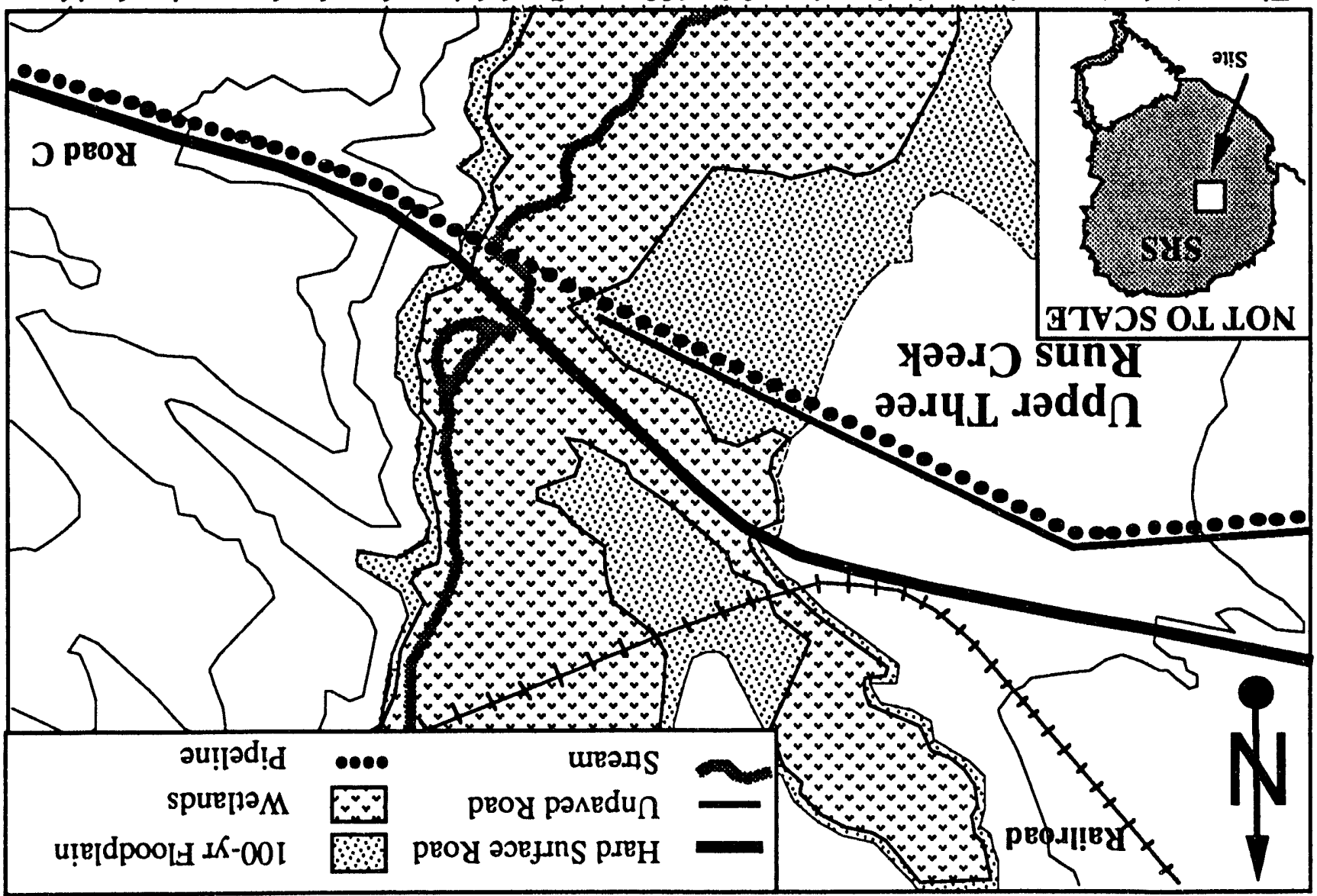




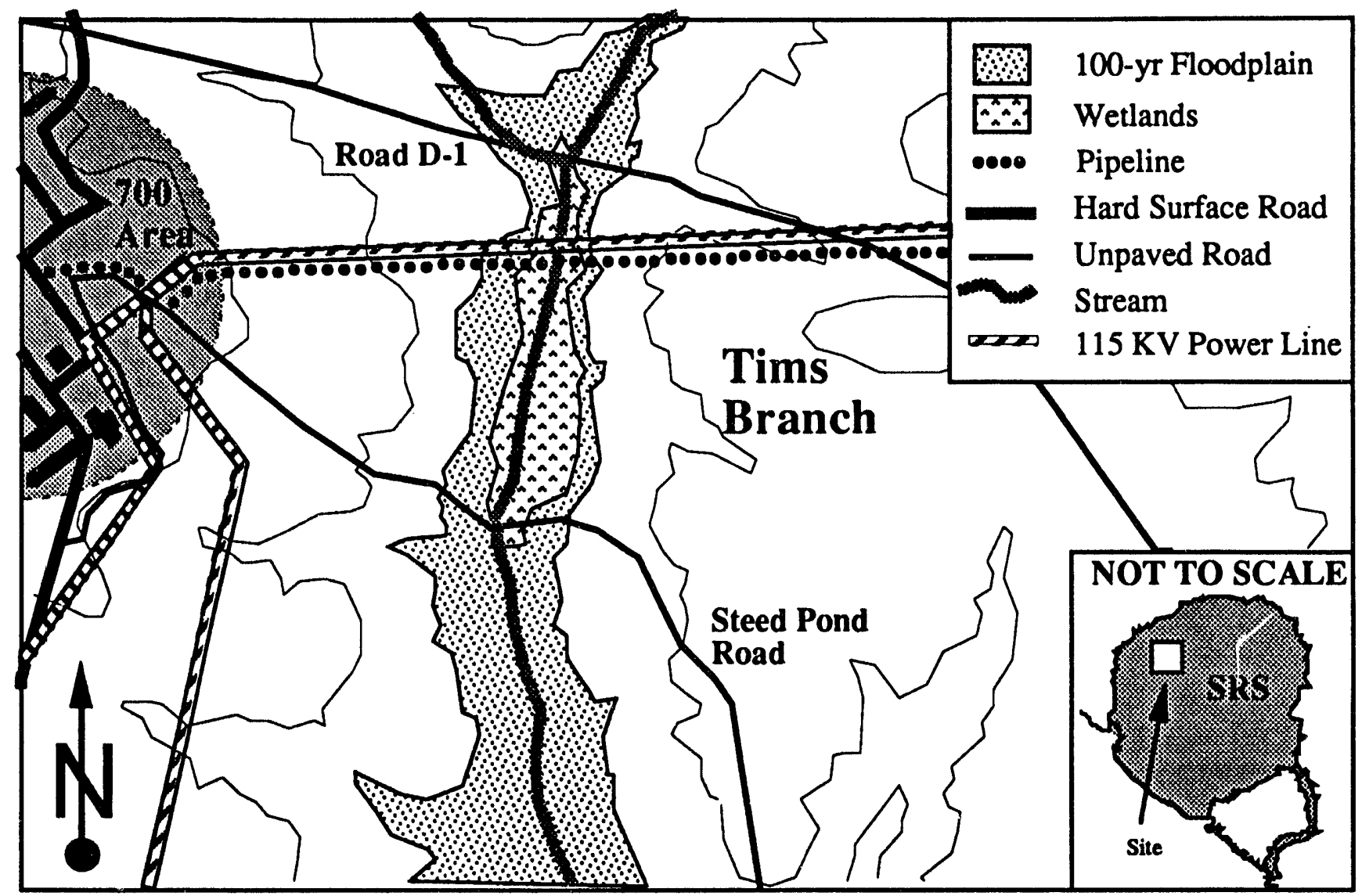

Figure A-3. Approximate site location of the 100-year floodplain and wetlands associated with the domestic water pipeline crossing of Tims Branch at 115KV Transmission Line.

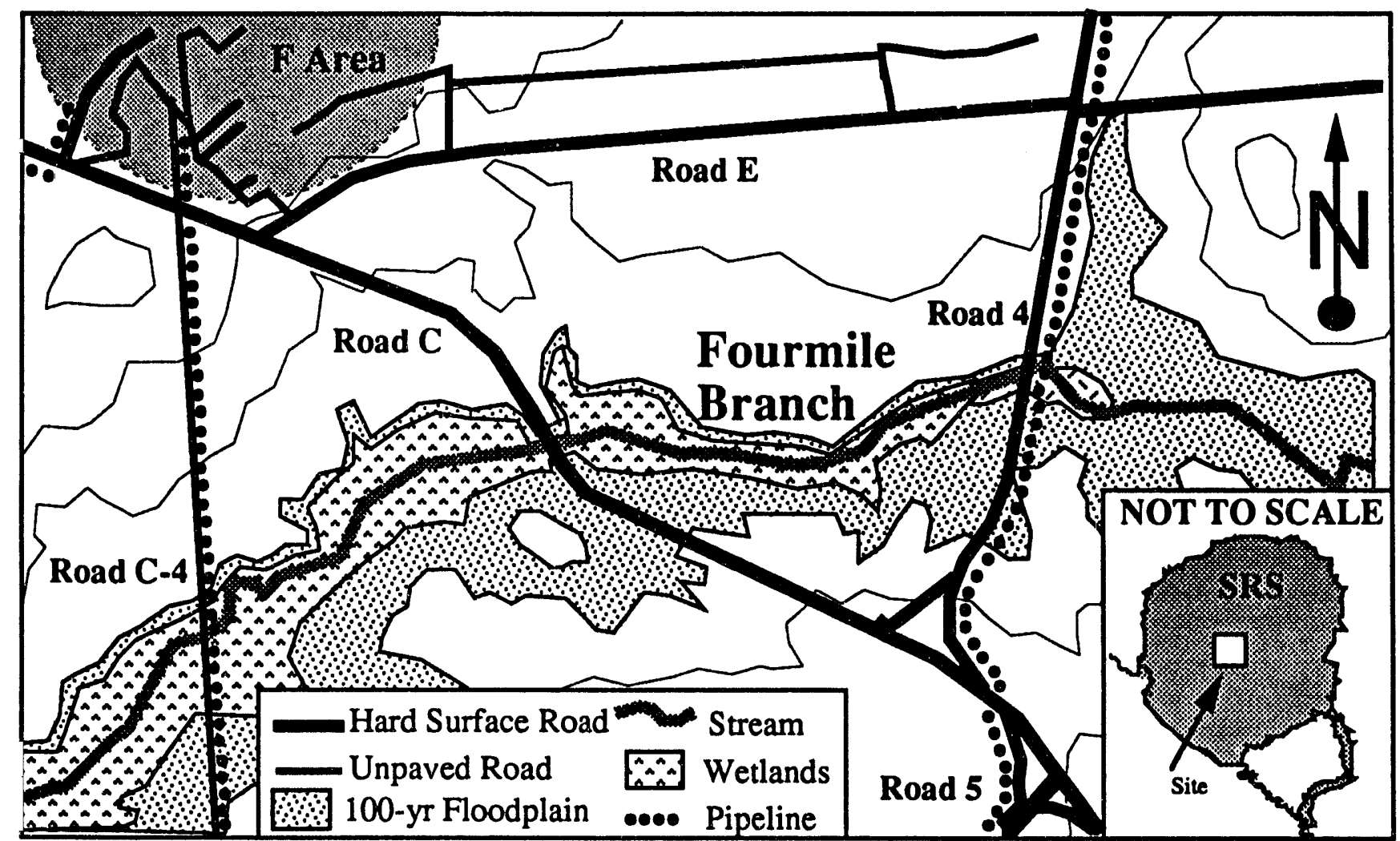

Figure A-4. Approximate site location of the 100-year floodplain and wetlands associated with the domestic water pipeline crossing of Fourmile Branch at SRS Roads C-4 and 4. 


\section{FINDING OF NO SIGNIFICANT IMPACT \\ AND FLOODPLAIN STATEMENT OF FINDINGS FOR \\ THE DOMESTIC WATER UPGRADES AND CONSOLIDATION \\ SAVANNAH RIVER SITE, AIKEN, SC}

\section{AGENCY: U.S. Department of Energy}

ACTION: Finding of No Significant Impact and Floodplain Statement of Findings

SUMMARY: The Department of Energy (DOE) has prepared an Environmental Assessment (EA), DOE/EA-0943, for the proposed upgrades and consolidation of the domestic water supply systems on the Savannah River Site (SRS), near Aiken, South Carolina. Based on the analyses in the EA, DOE has determined that the proposed action is not a major Federal action significantly affecting the quality of the human environment within the meaning of the National Environmental Policy Act (NEPA). Therefore, an environmental impact statement (EIS) is not required, and DOE is issuing this Finding of No Significant Impact and Floodplain Statement of Findings.

PUBLIC AVAILABILITY: Copies of the EA are available from:

Mr. Kart E. Goodwin

Office of Processing and Reactor Facilities

Office of Defense Programs, DP-636

U.S. Department of Energy 1000 Independence Avenue, S.W.

Washington, D.C. 20585

Phone: (301) 903-5498

For further information on the DOE NEPA process, contact:

Ms. Carol Borgstrom

Office of NEPA Oversight, EH-25

U.S. Department of Energy

1000 Independence Avenue, S.W.

Washington, D.C. 20585

Phone: (202) 586-4600 or (800) 472-2756 
BACKGROUND: Most of the domestic water facilities on SRS were originally constructed during the 1950's and are now experiencing difficulty in complying with current domestic water regulations. Specifically, these facilities face an ever increasing difficulty in complying with the Safe Drinking Water Act and South Carolina Department of Health and Environmental Control (SCDHEC) Drinking Water Regulations (R61-58). Audits of ground water based domestic water systems conducted by SCDHEC in 1986, 1988, 1991, and 1993 identified shortfalls in SRS domestic water systems meeting the requirements for secondary maximum containment levels (MCL's), as well as shortfalls in SCDHEC design standards. Secondary MCL's are those items that do not pose a direct health impact, such as odor or appearance.

PROPOSED ACTION: The proposed action would correct the discrepancies in SRS domestic water facilities by upgrading and consolidating existing domestic water facilities. The proposed upgrades would include replacement of existing domestic water distribution systems in A, B, D, N, T Areas, and the U.S. Forestry Service Station with corrosion resistant looped piping, installation of blow-off valves, and installation of isolation flush, and air relief valves. In addition, the project would also include installation of looped underground piping to consolidate the supply systems for A, B, C, F, H, N, S, Z Areas, and the U.S. Forestry Service Station into a single operational system. A domestic water tie-in-line to consolidate $D$ and $T$ Areas into one operational system would also be installed.

Two elevated water storage tanks would be installed on the consolidated loop. A new domestic water chemical treatment facility in B Area would be upgraded to serve as a backup for the A Area plant. Control and monitoring instrumentation would be installed to allow communication from the water treatment facilities, the consolidated loop system, and the elevated storage tanks. 
ALTERNATIVES CONSIDERED: In addition to the proposed action, DOE considered the following alternatives:

(1) No-Action (i.e., continued use of the existing SRS domestic water facilities).

(2) Upgrade of the individual operational area domestic water facilities.

(3) 14 separate upgrade and consolidation altematives.

The no-action altemative would not comply with applicable State and Federal regulations and is therefore not a reasonable alternative. The other altematives that would meet the need for DOE action were analyzed and were not selected. Upgrading of the individual area domestic water facilities would be too costly and unreliable. The 14 altemative upgrade and consolidation scenarios were all rejected because of various expense and reliability factors. These altemative upgrade and consolidation scenarios ranged from a single site-wide consolidated domestic water system that serviced all operational areas, guard posts, and pump houses, to a segmented partially-looped domestic water supply systems that would tie in with the adjacent two of Jackson, South Carolina.

ENVIRONMENTAL IMPACTS: The construction of the new A Area domestic water treatment facility, installation of upgrade piping within operational areas, and installation of consolidation piping between operational areas would not result in the discemable loss of any agricultural resources. All activities connected with the proposed action would occur within previously developed areas, or within the right-of-way of existing roadways, power lines, and steam lines. No threatened or endangered species would be affected by the proposed project. Facilities operation would have no adverse environmental impacts due to hazardous chemical or material use. There would be minor, temporary disturbance of floodplains/wetlands during the construction phase, and original contours would be restored after construction. There would be no impact to cultural resources, transportation, or local socioeconomic conditions. No health or safety 
concerns would be created. No cumulative impacts to the environment would be expected as a result of the proposed action.

FLOODPLAIN STATEMENT OF FINDINGS: This is a Floodplain Statement of Findings prepared in accordance with 10 CFR Part 1022. A Notice of Floodplain and Wetlands Involvement was published in May 18, 1994 (59 Fed. Reg. 25898), and a Floodplains and Wetlands Assessment was incorporated into the Environmental Assessment. As part of the upgrades and consolidation of domestic water facilities at SRS, DOE would install domestic water pipelines to consolidate 10 operational areas of SRS into 2 consolidated systems. These pipelines would cross through or near the floodplains of Upper Three Runs Creek, Fourmile Branch, and Tims Branch. An erosion control plan would be developed as part of the Project Pollution Prevention Plan to ensure that erosion and sedimentation would not cause adverse impacts to the floodplains. DOE would allow at least 15 days or public review after publication of this statement of findings before implementing the proposed action.

DETERMINATION: Based on the information and analyses in the EA, DOE has determined that the proposed upgrade and consolidation of the existing domestic water facilities at SRS does not constitute a major Federal action significantly affecting the quality of the human environment with the meaning of NEPA. Therefore, an environmental impact statement is not required.

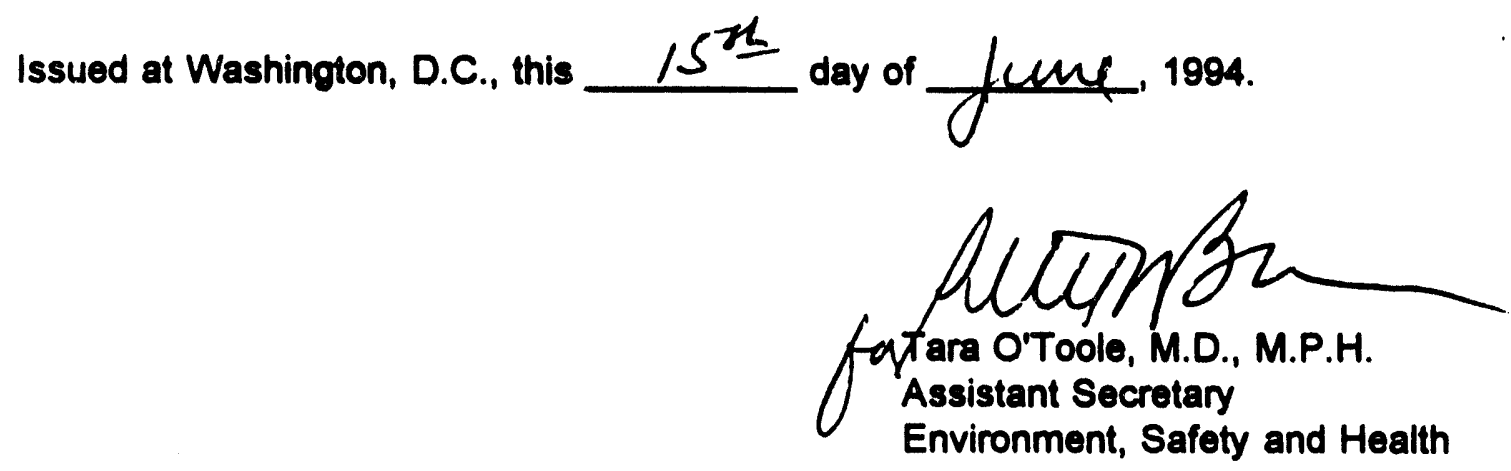


A01 US SENATE THE HONORABLE PAUL COVERDELL 204 RIJSSEL SENATE OFFICE BUILDING WASHINGTON DC 20510

A01 US SENATE

THE HONORABLE ERNEST F HOLLINGS

112 CUSTOM HOUSE

200 EAST BAY STREET

CHARLESTON SC 29401

A01 US SENATE

THE HONORABLE SAM NUNN

75 SPRING STREET SW

ATLANTA GA 30303

A01 US SENATE

THE HONORABLESTROM THURMOND 1558 STROM THURMOND FEDERAL BUILDING 1835 ASSEMBLY STREET

COLUMBIA SC 29201

\section{A02 US HOUSE OF REPRESENTATTVES}

THE HONORABLE BUTLER DERRICK

315 SOUTH MCDUFFIE STREET

PO BOX 4126

ANDERSON SC 29622

A02 US HOUSE OF REPRESENTATIVES THL AONORABLEFLOYD SPENCE

220 STONERIDGE DR \#202

COLUMBIA SC 29210-8018

BOI SC SENATE

THE HONORABLE HOLLY A CORK

SOUTH CAROLINA SENATE

3 RAINBOW ROW

HIL.TON HEAD ISLAND SC 29938

BO1 SC SENATE

THE HONORABLE JOHN MATTHEWS

SOUTH CAROLINA SENATE

PO BOX 401

SANTEE SC 29142

B01 SC SENATE

THE HONORABLE THOMAS L MOORE

SOUTHCAROLINA SENATE

PO BOX 684

CLEARWATER SC 29822

B01 SC SENATE

TIIE IIONORABLE NIKKI G SETZIER

SOUTHCAROLINA SENATE

1309 CANARY DRIVE

COLUMBIA SC 29169
BO1 SC SENATE

THE HONORABLE MARSHALL WILLIAMS SOUTH CAROLINA SENATE

PO BOX 1084

ORANGEBURG SC 29116

B01 SC SENATE

THE HONORABLE ADDISON JOE WILSON

SOUTH CAROLINA SENATE

606 GRESSETTE BUILDING

COLUMBIA SC 29202

B02 SC HOUSE OF REPRESENTATTVES THE HONORABLE WILLIAM S HOUCK $\mathbb{R}$ 314A BLATT BULDDING

COLUMBIA SC 29211

B02 SC HOUSE OF REPRESENTATIVES THE HONORABLE THOMASE HUFF 1751 GREGORY LAKE ROAD NORTH AUGUSTA SC 29841

B02 SC HOUSE OF REPRESENTATTVES THE HONORABLE BILLY KEYSERLING PO BOX 2145

BEAUFORT SC 29901

B02 SC HOUSE OF REPRESENTATIVES THE HONORABLE DOUGLAS E MCTEER BOX 97

EARLY BRANCH SC 29916

B02 SC HOUSE OF REPRESENTATIVES THE HONORABLE SCOTT RICHARDSON 52 NORTH ACLIBOGUE ROAD

HILTON HEAD ISLAND SC 29928

B02 SC HOUSE OF REPRESENTATIVES THE HONORABLE THOMAS ROAD RFD2 BOX 108A

BRANCHVILLE SC 29432

B02 SC HOUSE OF REPRESENTATTVES THE HONORABLE TTMOTHY FOI.K ROGFRS

530A BL.ATT BULLDING

COL.UMBIA SC 29211

B02 SC HOUSE OF REPRESENTATIVES IIEE HONORABLE IRENE K RUDNICK PO BOX 544

AIKLN SC 29802

B02. SC HOUSE OF REPRESENTATIVES TTIE HONORABLE CHLARLES SHARPE PO BOX 652

WAGENER SC 29164 
B02 SC HOUSE OF REPRESENTATIVES THE HONORABLE J ROLAND SMITH 310A BLATT BUILDING

COLUMBIA SC 29211

B02 SC HOUSE OF REPRESENTATTVES THE HONORABLE MOLLY SPEARMAN ROUTE 1 BOX 151

SALUDA SC 29138

B02 SC HOUSE OF REPRESENTATIVES THE HONORABLE CHARLES STONE ROUTE 3 BOX 109

EDGEFIELD SC 29824

B02 SC HOUSE OF REPRESENTATIVES THE HONORABLE CANDY Y WATTES 310B BLATT BUIL.DING

COLUMBIA SC 29211

B02 SC HOUSE OF REPRESENTATIVES THE HONORABLE JUANTTA M WHITE RT 1 BOX 184A

HARDEEVILLE SC 29927

B02 SC HOUSE OF REPRESENTATTVES THE HONORABLE JOSEPH B WILDER BOX 447

BARNWELL SC 29812

BOS SC STATEWIDE OFFICES

ATTN NUCLEAR ADVISORY COUNCIL 1205 PENDLETON STREET

COLUMBIA SC 29201

B05 SC STATEWIDE OFFICES

THE HONORABLE CARROLL A CAMPBEL L GOVERNOR OF SOUTH CAROLINA

BOX 11369

COLUMBIA SC 29211

B05 SC STATEWIDE OFFICES

THE HONORABLE T TRAVIS MEDLOCK

ATTORNEY GENERAL

STATE OF SOUTH CAROLINA

PO BOX 11549

COIUMRIA SC 29211

BOS SC STATEWIDE OFFICES

TIIE HONORABI.E NICK A THFODORF:

LIEUTENANT GOVERNOR OF SOUTH CAROLINA

BOX 142

COLUMBIA SC 29202
B08 SOUTH CAROLINA MAYORS

THE HONORABLE FRED B CAVANAUGH JR

MAYOR OF AIKEN

PO BOX 1177

AIKEN SC 29802

B08 SOUTH CAROLINA MAYORS

THE HONORABLEOLIVIA COHEN

MAYOR OF FAIRFAX

PO BOX 405

FAIRFAX SC 29827

B08 SOUTH CAROLINA MAYORS

THE HONORABLE HARVEY W EWING $\mathbb{R}$ MAYOR OF HIL.TON HEAD ISLAND PO BOX 22779

HILTON HEAD ISLAND SC 29925

B08 SOUTH CAROLINA MAYORS

THE HONORABLE THOMAS W GREENE

MAYOR OF NORTH AUGUSTA

PO BOX 6400

NORTH AUGUSTA SC 29841

B08 SOUTH CAROLINA MAYORS

THE HONORABLE PAUL K GREENE

MAYOR OF JACKSON

106 MAIN STREET

PO BOX 386

JACKSON SC 29831

B08 SOUTH CAROLINA MAYORS

THE HONORABLE ART HANNA

MAYOR OF NEW EULNTON

PO BOX DRAWER 479

NEW ELLENTON SC 29809

B08 SOUTH CAROLINA MAYORS

THE HONORABLE WILIIAM HOLMES

MAYOR OF AUENDALE

CITY HALL

PO BOX 551

ALLENDALE SC 29810

B08 SOUTH CAROLINA MAYORS

THE HONORABLE RICHARD E LAMAR

MAYOR OF BLACKVILLE

PO BOX 305

BLACK VILLE SC 29817

BO8 SOUTH CAROLINA MAYORS

TTE HONORABLE HAROLD MCMIIIEN

MAYOR OF HAMPTON

608 FIRST STREET WEST

IIAMPTON SC 29924 
B08 SOUTH CAROLINA MAYORS

THE HONORABLE ET MOORE

MAYOR OF SNELLING

P O BOX 392

BARNWELL SC 29812-9330

B08 SOUTH CAROLINA MAYORS

THE HONORABLE THOMAS R RIVERS

MAYOR OF WILLISTON

PO BOX 414

WILLISTON SC 29853

B08 SOUTH CAROLINA MAYORS

THE HONORABLE H CREECH SANDERS

MAYOR OF BARNWELL

PO BOX 776

BARNWEIL SC 29812

B08 SOUTH CAROLINA MAYORS

THE HONORABLE DAVID M TAUB

MAYOR OF BEAUFORT

414 NEW STREET

BEAUFORT SC 29902

C01 SOUTH CAROLINA STATEROCAL AGENCIES DIVISION OF ENERGY AGRICULTURE AND NATURAL RESOURCES

EDGAR A BROWN BUILDING

SUITE 333

1205 PENDLETON STREET

COLUMBIA SC 29201

C01 SOUTH CAROLINA STATEROCAL AGENCIES DIRECTOR AIKEN COUNTY PLANNING COMMISSION 828 RICHILAND AVENUEW

AIKEN SC 29801

C01 SOUTH CAROLINA STATEROCAL AGENCIES AUENDALE COUNTY ADMINISTRATOR

PO BOX 677

ALLENDALE SC 29810

C01 SOUTH CAROLINA STATE/LCAL AGENCIES COUNTY ADMINISTRATOR AIKEN COUNTY

828 RICHILAND AVENUE W

AIKEN SC $2960 \mathrm{i}$

C01 SOUTH CAROLINA STATEROCAL AGENCIES DIRECTOR

PUBLIC SAFETY OFFICE

CITY OF AIKEN

PO BOX 1177

AIKEN SC 29802
C01 SOUTII CAROLINA STATEROCAL AGENCIES

CITY ADMINISTRATOR

CITY OF NORTH AUGUSTA

PO BOX 6400

NORTH AUGUSTA SC 29841

C01 SOUTH CAROLINA STATEROCAL AGENCIES BUREAU OF SOLID AND HAZARDOUS WASTE DIVISION OF HYDROGEOLOGY

SOUTH CAROLINA DEPARTMENT OF HEALTH AND ENVIRONMENTAL CONTROL

2600 BULL. STREET

COLUMBLA SC 29201

C01 SOUTH CAROLINA STATEROCAL AGENCIES

CHIEF

BUREAU OF ENVIRONMENTAL QUALITY CONTROL LABS

SOUTH CAROLINA DEPARTMENT OF HEALTH AND

ENVIRONMENTAL CONTROL.

2600 BULL STREET

COLUMBIA SC 29201

CO1 SOUTH CAROLINA STATEROCAL AGENCIES

CHAIRMAN

JACKSON TOWN COUNCIL.

BOX 102

JACKSON SC 29831

C01 SOUTH CAROLINA STATEROCAL AGENCIES COMMISSIONER

SOUTH CAROLINA DEPARTMENT OF HEALTH AND ENVIRONMENTAL CONTROL

2600 BULL. STREET

COLUMBLA SC 29201

C01 SOUTH CAROLINA STATEROCAL AGENCIES

CHIEF

BUREAU OF WATER POLLUTION CONTROL SOUTH CAROLINA DEPARTMENT OF HEALTH AND ENVIRONMENTAL CONTROL

2600 BULL STREET

COLUMBLA SC 29201

C01 SOUTH CAROLINA STATEROCAL AGENCIES

LEGAL COUNSEL

WATER RESOURCES COMMISSION

SIAIE OF SOUTH CAROLINA

1201 MAIN STREET

SUITE 1100

CAPITOL CENTTR

COLUMBLA SC 29201

COI SOUTII CAROLINA STATEROCAL AGENCIES DIRECTOR

LOW COUNTRY COUNCLL OF GOVFRNMENTS

PO BOX 98

YEMASSEF SC 29445 
C01 SOUTH CAROLINA STATEROCAL AGENCIES

CHIFF

BUREAU OF DRINKING WATER PROTTECTION

SOUTH CAROLINA DEPARTMENT OF HEALTH AND ENVIRONMENTAL CONTROL

2600 BULL STREET

COLUMBLA SC 29201

C01 SOUTH CAROLINA STATEROCAL AGENCIES COORDINATOR

AIKEN COUNTY CIVIL DEFENSE

828 RICHLAND A VENUE W

AIKEN SC 29801

C01 SOUTH CAROLINA STATEROCAL AGENCIES GENERAL MANAGER

BEAUFORT-JASPER WATER \& SEWER AUTHORITY PO BOX 2149

BEAUFORT SC 29901-2149

C01 SOUTH CAROLINA STATEROCAL AGENCIES STATE GEOLOGIST

SOUTH CAROLINA GEOLOGICAL SURVEY

5 GEOLOGY ROAD

COLUMBLA SC 29210

C01 SOUTH CAROLINA STATEROCAL AGENCIES CHIEF

BUREAU OF AIR QUALTTY CONTROL

SOUTH CAROLINA DEPARTMENT OF HEALTH AND ENVIRONMENTAL CONTROL

2600 BULL STREET

COLUMBIA SC 29201

C01 SOUTH CAROLINA STATEROCAL AGENCIES CHAIRMAN OF THE BOARD

BEAUFORT-JASPER WATER \& SEWER AUTHORITY PO BOX 2149

BEAUFORT SC 29901-2149

C01 SOUTH CAROLINA STATEROCAL AGENCIES RICHLAND COUNTY COUNCLL 3333 HEYWARD STREET

COLUMBIA SC 29205

C01 SOUTH C CARCLUVA STATELOCAL ALENCLIS BEAUFORT-JASPER WATER \& SEWER AUTHORITY PO BOX 2149

BEAUFORT SC 29901-2149

CO1 SOUTH CAROLINA STATELOCAL AGENCIES DEPUTY COMMISSIONER

ENVIRONMENTAL QUALTTY CONTROL

SOUTH CAROLINA DEPARTMENT OF HEALTH AND ENVIRONMENTAL CONTROL

2600 BULL STREET

COLUMBIA SC 22201
C01 SOUTH CAROLINA STATEROCAL AGENCIES CHIEF

BUREAU OF RADIOLOGICAL HEALTH

SOUTH CAROLINA DEPARTMENT OF HEALTH AND ENVIRONMENTAL CONTROL

2600 BULL. STREET

COLUMBLA SC 29201

C01 SOUTH CAROLINA STATEROCAL AGENCIES DEPUTY DIRECTOR

WATER RESOURCES COMMISSION

STATE OF SOUTH CAROLINA

1201 MAIN STREET

SUITE 1100

CAPITOL CENTER

COLUMBIA SC 29201

C01 SOUTH CAROLINA STATEROCAL AGENCIES DIRECTOR

SOUTH CAROLINA STATE DEVELOPMENT BOARD PO BOX 927

COLUMBLA SC 29202

C01 SOUTH CAROLINA STATEROCAL AGENCIES CHIEF

BUREAU OF SOLID AND HAZARDOUS WASTE MANAGEMENT SOUTH CAROLINA DEPARTMENT OF HEALTH AND ENVIRONMENTAL CONTROL

2600 BULL STREET

COLUMBIA SC 29201

C01 SOUTH CAROLINA STATEROCAL AGENCIES

EXECUTIVE DIRECTOR

WATER RESOURCES COMMISSION

STATE OF SOUTH CAROLINA

1201 MAIN STREET

SUITE 1100

CAPITOL CENTER

COLUMBIA SC 29201

C01 SOUTH CAROLINA STATEROCAL AGENCIES CHAIRMAN

ALLENDALECITY COUNCIL

PO BOX 338

FAIRFAX SC 29827

C01 SOUTH CAROLINA STATEROCAL AGENCIES CTTY MANAGER

CITY OF AIKEN

PO BOX 1177

AIKEN SC 29802

C01 SOUTH CAROLINA STATEROCAL AGENCIES

CITY MANAGER

CITY OF BEAUFORT

CITY HALL

302 CARTERET STREET

BEAUIORT SC 29901 
C01 SOUTH CAROLINA STATEROCAL AGENCIES CHAIRMAN

AIKEN COUNTY COUNCIL.

828 RICHLAND AVENUE W

AIKEN SC 29801

C01 SOUTH CAROLINA ITATEROCAL AGENCIES ADMINISTRATOR

BEAUFORT COUNTY

PO DRAWER 1228

BEAUFORT SC 29901

C01 GEORGLA STATEROCAL AGENCIES

CHAIRMAN

COLUMBLA COUNTY COMMISSION

630 WASHINGTON WEST DR

PO BOX 498

EVANS GA 30809

C01 GEORGLA STATEROCAL AGENCIES

ADMINISTRATOR

COLUMBIA COUNTY

PO BOX 498

EVANS GA 30809

C01 SOUTH CAROLINA STATEROCAL AGENCIES CHAIRMAN

BEAUFORT COUNTY COUNCIL

PO DRAWER 7923

HILTON HEAD ISLAND SC 29938

C01 SOUTH CAROLINA STATELOCAL AGENCIES ADMINISTRATOR

HAMPTON COUNTY

201 JACKSON STREET W

HAMPTON SC 29924

C01 SOUTH CAROLINA STATEROCAL AGENCIES ADMINISTRATOR

CITY OF NORTH AUGUSTA

PO BOX 6400

NORTH AUGUSTA SC 29841

C01 SOUTH CAROLINA STATEROCAL AGENCIES MR DANNY BLACK

CHAIRMAN

BARNWELL COUNTY COUNCIL

COUNTY OFFICE BUILDING

PO BOX 443

BARNWELL SC 29812

C01 SOUTH CAROLINA STATE/LOCAL AGENCIES MR ROBERT T BOLAND

ADMINISTRATOR

BARNWELL COUNTY COUNCIL

ROOM 101 COUNTY OFFICE BUILDING

BARNWELL SC 29812
C01 SOUTH CAROLINA STATEROCAL AGENCIES

MR LEE S BOWERS

CILAIRMAN

HLAMPTON COUNTY COUNCIL

PO BOX 40

ESTILLSC 29918

COI SOUTH CAROLINA STATEROCAL AGENCIES

SHARON CRIBB

SOUTH CAROLINA DEPARTMENT OF HEALTH AND

ENVIRONMENTAL CONTROL NUCLEAR EMERGENCY

PLANNING

BUREAU OF SOLID AND HAZARDOUS WASTE

2600 BULL STREET

COLUMBLA SC 29201

C01 SOUTH CAROLINA STATEROCAL AGENCIES

MR. JOE DENNIS

SOUTH CAROLINA WATER RESOURCES COMMISSION SOUTH CAROLINA PROJECT NOTIFICATION AND REVIEW 1201 MAIN STREET

SUITE 1100

COLUMBIA SC 29201

C01 SOUTH CAROLINA STATEROCAL AGENCIES

MR IAN D HILI.

INTERGOVERNMENTAL REVIEW COORDINATOR

STATE HISTORIC PRESERVATION OFFICE

SOUTH CAROLINA DEPARTMENT OF ARCHIVES AND HISTORY

1430 SENATE STREET

PO BOX 11669

COLUMBLA SC 29211

C01 SOUTH CAROLINA STATEROCAL AGENCIES

MRS PEGGY REINHART

C O BARNWEL $\perp$ COUNTY OFFICE BUIL.DING

BARNWELL SC 29812

C01 SOUTH CAROLINA STATEROCAL AGENCIES

STACY RICHARDSON

SOUTH CAROLINA DEPARTMENT OF HEALTH AND ENVIRONMENTAL CONTROL EQC ADMINISTRATION 2600 BULL STREET

COLUMBLA SC 29201

C01 SOUTH CAROLINA STATEROCAL AGENCIES MR STEVE RICHARDSON

SOUTH CAROLINA DEPARTMENT OF HEALTH AND ENVIRONMENTAL CONTROL I:QC ADMINISTRATION 2600 BULL STREET

COLUMBIA SC 29201 
C01 SOUTH CAROLNA STATEROCAL AGENCIES MR CARLISLE ROBERTS $\mathbb{R}$

GOVERNORS DIVISION OF NATURAL RESOURCES CO JOHN KEMP

SOUTH CAROLINA PROJECT NOTIFICATION AND REVIEW 1205 PENDLETON STREET

COLUMBLA SC 29201

C01 SOUTH CAROLINA STATEROCAL AGENCIES DR JAMES A TIMMERMAN JR EXECUTIVE DRECTOR SOUTH CAROLINA WILDLIFE AND MARINE RESOURCES DEPARTMENT

PO BOX 167

COLUMBLA SC 29202

CABOI CIIIZENS ADVISORY BOARD MEMBER MS JULIE ARBOGAST

RT 2 BOX 371

BARNWELL SC 29812

CAB01 CTIIZENS ADVISORY BOARD MEMBER MS ANNEN BROWN

275 DUNCAN ROAD

NORTH AUGUSTA SC 29841

CABOI CIIIZENS ADVISORY BOARD MEMBER MS LENOLA COOKS

1715 OLD EDGEFIEID RD

NORTH AUGUSTA SC 29841

CABOI CITIZENS ADVISORY BOARD MEMBER MR THOMAS W COSTIKYAN

6 DOE PONNT

DATAW ISLAND SC 29920

CAB01 CITLENS ADVISORY BOARD MEMBER

NR BRIAN COSTNER

ENERGY RESEARCH FOUNDATION

537 HARDEN STREET

COLUMBLA SC 29205

CAB01 CITLENS ADVISORY BOARD MEMBER MR JEFF CRANE US ENVTRONMENTAL PROTECTION AGENCY REGION IV SRS REMEDIAL PROJECT MANAGER

345 COURTLAND STREET NE

ATLANTA GA 30365

CABOI CITTZENS ADVISORY BOARD MEMBER MR MIES N GRANT

SOS IIILL PLACE:

BRUNSWICK GA 31520
CABO 1 CTTLZENS ADVISORY BOARD MEMBER MR THOMAS GREENE

1919 BYRNES ROAD

NORTH AUGUSTA SC 29841

CAB01 CTILENS ADVISORY BOARD MEMBER MS RACHAEL KEARSE HARPER

PO BOX 98

ESTILL SC 29918

CABO1 CTTLEENS ADVISORY BOARD MEMBER MR THOMAS F HEENAN

ASSISTANT MANAGER FOR ENVIRONMENTAL RESTORATION AND SOLID WASTE

US DEPARTMENT OF ENERGY

PO BOX A

AIKEN SC 29802

CAB01 CTITZENS ADVISORY BOARD MEMBER MS ALJCE HOLLINGSWORTH

STAR RT BOX 294 1/2

BEAUFORT SC 29902

CAB01 CTTIZENS ADVISORY BOARD MEMBER MR THELONIOUS A JONES

2010 LANIER ROAD

AUGUSTA GA 30909

CAB01 CITTZENS ADVISORY BOARD MEMBER REVEREND WALTER JONES

3637 NASSAU DRIVE

AUGUSTA GA 30909

CAB01 CITIZENS ADVISORY BOARD MEMBER MR HARRY JUE

WATER AND WASTEWATER OPERATIONS

CITY OF SAVANNAH

PO BOX 1027

SAVANNAH GA 31402

CABO1 CITIZENS ADVISORY BOARD MEMBER MS ANN G LOADHOLT

PO BOX 365

BARNWELL. SC 29812

CABO1 CITLENS ADVISORY BOARD MEMBER MS KATIIERINE MAY 3597 PEBBLE BEACH DRIVE MARTINEZ GA 30907

CABOI CITLAENS ADVISORY BOARD MEMBER MS MLDRED MCCIAIN

7ก MAUPAS AVTENUT:

SAVANNAII GA 31401 
CABO1 CITZENS ADVISORY BOARD MEMBER MS JOSEPHINE A NESTOR

3371 LAKE FOREST VILLAS

HII TON HEAD ISLAND SC 29928

CAB01 CITZENS ADVISORY BOARD MEMBER MR LANE D PARKER 110 GREENLAND DRIVE

NORTH AUGUSTA SC 29841

CAB01 CITLENS ADVISORY BOARD MEMBER MS FRANCIS ANN RAGAN

FEDERAL FACILITY LIAISON

ENVIRONMENTAL QUALTYY CONTROL

SC DEPARTMENT OF HEALTH AND ENVIRONMENTAL CONTROL

2600 BULL STREET

COLUMBIA SC 29201

CABOI CITLEENS ADVISORY BOARD MEMBER

DR KAMALAKAR B RAUT

708 PENN WALLER ROAD

SAVANNAH GA 31410

CAB01 CITIZENS ADVISORY BOARD MEMBER MS MYRA REECE

DIRECTOR LOWER SAVANNAH DISTRICT OFFICE SC DEPARTMENT OF HEALTH AND ENVIRONMENTAL CONTROL

218 BEAUFORT ST NE

AIKEN SC 29801

CAB01 CITIZENS ADVISORY BOARD MEMBER MR STEVEN D RICHARDSON ASSISTANT MANAGER FOR HIGHLEVEL WASTE US DEPARTMENT OF ENERGY

POBOX A

AIKEN SC 29802

CAB01 CITIZENS ADVISORY BOARD MEMBER MR ROBERT H SLAY

PO BOX 192

BEECH ISLAND SC 29842

CABO1 CITZENS ADVISORY BOARD MEMBER MS PERJETTA K SMITH

128 WINDY MILL DRIVE

NORTH AUGUSTA SC 29841

CABO1 CITZZENS ADVISORY BOARD MEMBFR

MR MOSES TODD

RICIMOND COUNTY BOARD OF COMMISSIONERS

COUNTY MUNICTPAL. BLDG

ROOM 605

530 GREENE STREET

AUGUSTA GA 30911
CABO1 CITIZENS ADVISORY BOARD MEMBER

MS CAMILLA WARREN

CHIEF DOE REMEDIAL SECTION

US ENVIRONMENTAL PROTECTION AGENCY

345 COURTLAND STREET NE

ATLANTA GA 30365

CABO1 CITIZENS ADVISORY BOARD MEMBER MS BEAURINE H WILKINS

2524 RHODES DRIVE

AUGUSTA GA 30906

D01 GEORGLA SENATE

THE HONORABLE FRANK A ALBERT

GEORGLA SENATE

PO BOX 1461

AUGUSTA GA 30903

D01 GEORGLA SENATE

THE HONORABLE DONALD ECHEEKS

3047 WALTON WAY

AUGUSTA GA 30909

D01 GEORGLA SENATE

THE HONORABLE J TOM COLEMAN

GEORGIA SENATE

PO BOX 22398

SAVANNAH GA 31403

D01 GEORGLA SENATE

THE HONON'ABI E CHARLES W WALKER

GEORGLA SENATE

1143 LANEY WALKER BLVD

AUGUSTA GA 30901

D02 GEORGLA HOUSE OF REPRESENTATTVES THE HONORABLE GEORGE M BROWN

PO BOX 1114

AUGUSTA GA 30903

D02 GEORGLA HOUSE OF REPRESENTATTVES

THE HONORABLE JACK CONNEL $\perp$

PO BOX 308

AUGUSTA GA 30903

D02 GEORGLA HOUSE OF REPRESENTATIVES TTIF: IIINORABI F SONNY DLXON

74 BATEMORE AVENUE

PO BOX 18266

GARDEN CITY GA 31408

D02 GEORGLA HOUSE OF REPRESENTATIVES

TIIIE IIONORABLE MARTILA MOORE

12 PLANTATION HILLS DRIVE

EVANS GA 30809 
D02 GEORGIA HOUSE OF REPRESENTATIVES THE HONORABLE MIKE PADGETT

1140 BENNOCK MILL ROAD

AUGUSTA GA 30906

D02 GEORGLA HOUSE OF REPRESENTATIVES THE HONORABLEROBIN L WILLIAMS 3322 WHEEL ER ROAD

AUGUSTA GA 30909

DOS GA STATEWIDE OFFICES

THE HONORABLE PIERRE HOWARD LIEUTENANT GOVERNOR OF GEORGIA 240 STATE CAPITAL

ATLANTA GA 30334

D05 GEORGIA STATEWIDE OFFICES

THE HONORABLEZEUL MILIER

GOVERNOR OF GEORGLA

240 STATE CAPITAL

ATLANTA GA 30335

D08 GEORGLA MAYORS

THE HONORABLEGEORGEL DELOACH

MAYOR OF WAYNESBORO

628 MYRICK STREET

WAYNESBORO GA 30830

D08 GEORGIA MAYORS

THE HONORABLECHARLES A DEVANEY

MAYOR OF AUGUSTA

CITY COUNTY BUILDING

530 GREENE STREET

AUGUSTA GA 30911

E01 GEORGIA STATE/OCAL AGENCIES

DIRECTOR

AUGUSTA-RICHMOND COUNTY PLAANNING COMMISSION

S25 TELFAIR STREET

AUGUSTA GA 30911

E01 GEORGIA STATEROCAL AGENCIES

BURKE COUNTY

COUNTY ADMINISTRATOR

PO BOX 62

WAYNESBORO GA 30830

E01 GEORGIA STATE/LCAL AGENCIES

CHAIRMAN

BURKE COUNTY COMMISSIONERS

BURKE COUNTY COURTHOUSE

PO BOX 62

WAYNESBORO GA 30830
E01 GEORGIA STATEROCAL AGENCIES

DIRECTOR

CENTRAL SAVANNAH RIVER AREA PLANNING AND DEVELOPMENT COMMISSION

2123 WRIGHTSBORO ROAD

PO BOX 2800

AUGUSTA GA 30904

E01 GEORGIA STATEROCAL AGENCIES

MR J L SETSER

PROGRAM COORDINATION BRANCH

ENVIRONMENTAL RADIATION PROGRAMS

ENVIRONMENTAL PROTECTION DIVISION

GEORGLA DEPARTMENT OF NATURAL RESOURCES

SUITE 1152

EAST TOWFR

FLOYD BUILDING

205 BUTLER STREET

ATLANTA GA 30334

E01 GEORGIA STATE/LOCAL AGENCIES

MR J D TANNER

GEORGLA DEPARTMENT OF NATURAL RESOURCES

SUITE 1152

EAST TOWER

FLOYD BUILDING

205 BUTLER STREET

ATLANTA GA 30334

F01 FEDERAL AGENCIES

US ENVIRONMENTAL PROTECTION AGENCY

REGION IV

3-AIR

ATTN JOHN RICHARDS

345 COURTLAND STREET NE

ATLANTA GA 30365

F01 FEDERAL AGENCIES

MR WILLLAM ABERCROMBIE

STATE CONSERVATIONIST

SOIL CONSER VATION SERVICE

US DEPARTMENT OF AGRICULTURE

1835 ASSEMBLY STREET

ROOM 950

COLUMBLA SC 29201

F01 FEDERAL AGENCIES

MR JOHN E ALCOCK

REGIONAL FORESTER

SOUTHERN REGIONAL OFFICE

FOREST SER VICE

US DEPARTMENT OF AGRICULTURE

1720 PEACHIREE ROAD NW

ATLANTA GA 30367 
F01 FEDERAL AGENCIES

MR ROGER L BANKS

FIELD OFFICE SUPERVISOR

ENDANGERED SPECIES OFFICE

FISH AND WILDLIFE SERVICE

US DEPARTMENT OF THE INTERIOR

PO BOX 12559

CHARLESTON SC 29412

F01 FEDERAL AGENCIES

MR DAVID COLEMAN

SAVANNAH DISTRICT

SAS-PD-E1

US ARMY CORPS OF ENGINEERS

PO BOX 889

SAVANNAH GA 31402

F01 FEDERAL AGENCIES

MR STEVE GILBRT

FISH AND WILDLIFE SERVICE

US DEPARTMENT OF THE INTERIOR

PO BOX 12559

CHARLESTON SC 29412

F01 FEDERAL AGENCIES

MR CLARENCE HAM

CHARLESTON DISTRICT

SAC CO-P

US ARMY CORPS OF ENGINEERS

PO BOX 919

CHARLESTON SC 29402-0919

F01 FEDERAL AGENCIES

MR DAVID HOPKINS

DOE COORDINATOR

FEDERAL, ACTIVITIES BRANCH

US ENVIRONMENTAL PROTECTION AGENCY

REGION IV

345 COURTLAND STREET

ATLANTA GA 30365

F01 FEDERAL AGENCIES

MR ARTHUR G LINTON

FEDERAL FACILITIES COORDINATOR

FEDERAL ACTIVITIES BRANCH

OFFICE OF POLICY AND MANAGEMENT

US ENVIRONMENTAL PROTECTION AGENCY

REGLN IV

345 COURTLAND STREET NE

ATLANTA GA 30365

F01 FEDERAL AGENCIES

MR WARREN T PARKER

FLELD OFFICE SUPER VISOR

ENDANGERED SPECIES OFFICE

FISH AND WILDLIFE SERVICE

US DEPARTMENT OF ITE INTERIOR

330 RIDGEFIELDCT

ASHEVILLE NC 28806-2210
F01 FEDERAL AGENCIES

MR GLENN G PATTIERSON

DISTRICT CHIEF

WATER RESOURCES DIVISION

US GEOLOGICAL SURVEY

STROM THURMOND FEDERAL BUILDING

STEPHENSON OFFICE CENTER

SUITE 129

720 GRACERN ROAD

COLUMBIA SC 29210-7655

F01 FEDERAL AGENCIES

MR JAMES W PULLLAM JR

REGIONAL DIRECTOR (AE)

OFFICE OF THE ENVIRONMENT

FISH AND WILDLIFE SER VICE

US DEPARTMENT OF THE INTERIOR

RICHARD RUSSELL BUILDING

75 SPRING STREET

ATLANTA GA 30303

F01 FEDERAL AGENCIES

LT COLONEL JAMES T SCOTT

DISTRICT ENGINEER

CHARLESTON DISTRICT

SAC CO-P

US ARMY CORPS OF ENGINEERS

PO BOX 919

CILARLESTON SC 29402

F01 FEDERAL AGENCIES

MR GREER C TIDWEIL

ADMINISTRATOR

US ENVIRONMENTAL PROTECTION AGENCY REGION IV

345 COURTLAND STREET NE

ATLANTA GA 30365

G01 SC ENVIRONMENTAL GROUPS ANDOTHER INTEREST GROUPS

PRESIDENT

BARNWEL CILAMBER OF COMMERCE

2004 FINLEY DRIVE

BARNWELL SC 29812

G01 SC ENVIRONMENTAL GROUPS AND OTHER INTEREST GROUPS

THE AUDUBON SOCIETY

¿LIU DLEVINE SIREET

PO BOX 5923

COLUMBIA SC 29205

G01 SC ENVIRONMENTAL GROUPS AND OTHER INTEREST GROUPS

EXIECUTIVE DIRECTOR

THE SOUTH CAROLINA WILDLIFE FEDERATION

PO BOX 61159

COL.UMBIA SC 2926().1159 
G01 SC ENVIRONMENTAL GROUPS ANDOTHER INTEREST GROUPS

MR WALTER T AHEARN

THE SOUTH CAROLINA WILDLIFEFEDERATION 4512 OAKWOODRD

COLUMBLA SC 29260-1159

G01 SC ENVIRONMENTAL GROUPS ANDOTHER INTEREST GROUPS

DR HOWARD T GLCHRIST

FRIENDS OF THE SAVANNAH RIVER SITE

127 GREEN DRIVE

WILLISTON SC 29853

G01 SC ENVIRONMENTAL GROUPS ANDOTHER INTEREST GROUPS

DR MARY T KEULY

LEAGUE OF WOMEN VOTERS OF SOUTH CAROLINA

4018 SAND WOOD DR

COLUMBIA SC 29206

G02 GA ENVIRONMENTAL GROUPS AND OTHER PUBLIC INTEREST GROUPS

MR TOM CLEMENTS

GREENPEACE USA INC

20 13TH STREET

ATLANTA GA 30309

G02 GA ENVIRONMENTAL GROUPS AND OTHER INTEREST GROUPS

DR JUDTH E GORDON

NUCLEAR COORDINATOR

SOUTH CAROLINA CHAPTER

SIERRA CLUB

PO BOX 3434

AUGUSTA GA $30904-1434$

G02 GA ENVIRONMENTAL GROUPS AND OTHER INTEREST GROUPS

MR A K HASAN

FRIENDS OF THE SAVANNAH RIVER SITE

PO BOX 1837

AUGUSTA GA 30903-1837

G02 GA ENVIRONMENTAL GROUPS AND OTHER PUBLIC INTEREST GROUPS

MR ALBERT M HODGE JR

METRO AUGUSTA CHAMBER OF COMMERCE

PO BOX 657

AUGUSTA GA 30913

G02 GA ENVIRONMENTAL GROUPS AND OTHER PUBLIC INTEREST GROUPS

MS CHERYL D JAY

COASTAL CITLENS FOR A CLEAN ENVIRONMENT

10 HOPECREST AVENUE

SAVANNAII GA 31406
HO2 U.S. DEPARTMENT OF ENERGY - SR

MR RICHARD D BROOKS

PROGRAM MANAGER

USC DEPARTMENT OF ARCHAEOLOGY AND ANTHROPOLOGY US DEPARTMENT OF ENERGY

SAVANNAH RIVER OPERATIONS OFFICE

BUILDING 760-11G

P.O. BOX A

AIKEN SC 29802

101 NEWSPAPERS

AIKEN STANDARD

ATTN RODDIE BURRIS STAFF WRITER

124 RUTLAND DRIVE

AIKEN SC 29801

I01 NEWSPAPERS

ALENDALECOUNTY CITIZEN LEADER

ATTN EDITOR

PO BOX 98

ALLENDALE SC 29810

I01 NEWSPAPERS

THE AUGUSTA CHRONICLE

ATTN MANAGLNG EDITOR

725 BROAD STREET

PO BOX 1928

AUGUSTA GA 30901

101 NEWSPAPERS

AUGUSTA CHRONICIE

ATTN JOHN WINTERS

STAFF WRITER

619 MORRIS PLACE NE

WASHINGTON DC 20002

I01 NEWSPAPERS

SOUTH CAROLINA BLACK MEDIA

ATTN EDITOR

1310 HARDEN STREET

PO BOX 11128

COLUMBIA SC 29204

101 NEWSPAPERS

THE CHARLOTTE OBSITR VIFR

ATTN NEWS EDITOR

1338 MAIN STREET

COLUMBLA SC 29201

I01 NEWSPAPERS

THE COLUMBIA STAIT:RECORD

ATTN NEWS EDITOR

1401 SHOP ROAD

PO BOX 1333

COLUMBIA SC 29202 
101 NEWSPAPERS

THE HILTON HEAD ISLAND PACKET ATTN EDTTOR

NUMBER 1

POPEEXECUTIVE MALL

PO BOX 5727

HII TON HEAD ISLAND SC 29928

I01 NEWSPAPERS

NORTH AUGUSTA POST

ATTN MS. JOANNE RAINSFORD

S09 GEORGLA AVE

PO BOX 7800

NORTH AUGUSTA SC 29841

I01 NEWSPAPERS

THE SAVANNAH MORNING NEWS

ATTNEDTOR

PO BOX 1088

SAVANNAH GA 31402

I01 NEWSPAPERS

THE SAVANNAH MORNING NEWS

ATTN BRAD SWOOPE REPORTER

111 WEST BAY STREET

SAVANNAH GA 31401

I01 NEWSPAPERS

THE STAR

ATTN NEWS EDTTOR

106 BUENA VISTA AVE EAST

PO BOX 6095

NORTH AUGUSTA SC 29841

I01 NEWSPAPERS

THE STATE

ATTN CHLARLES POPE STAFF WRITER

1401 SHOP ROAD

PO BOX 1333

COLUMBIA SC 29202

I01 NEWSPAPERS

THE STATESBORO HERALD

ATINEDITOR

1 HERALD SQUARE

STATESBORC Gi jüjö

I01 NEWSPAPERS

TIIE WILLISTON WAY

ATTN NEWS EDITOR

PO BOX 1255

BARNWELL SC 29812-1255
I01 NEWSPAPERS

THE CHARLOTTE OBSER VER

ATTN JACK HORAN

STAFF WRITER

600 S TRYON STREET

PO BOX 2138

CHARLOTTE NC 28202

I02 TELEVISION

EXECUTIVE DIRECTOR

GEORGIA ETV NETWORK

1540 STEWARD AVENUE SW

ATLANTA GA 30310

I02 TELEVISION

MR BRIAN ROBERTS

WAGT-TV

CHANNEL 26

PO BOX 1526

AUGUSTA GA 30903

I02 TELEVISION

NEWS DIRECTOR

WIS-TV

CHANNEL 10

1111 BULL STREET

COLUMBIA SC 29202

I02 TELEVISION

MR MICHAEL FRANK

WJBF-TV

CHANNEL 6

PO BOX 1404

AUGUSTA GA 30903

I02 TEL EVISION

NEWS DIRECTOR

WLTX-TV

CHANNEL 19

PO DRAWER M

COLUMBIA SC 29250

I02 TEIEVISION

NEWS DIRECTOR

WOLO-TV

CHANNEL 25

PO BOX 4217

COI.LMBIA SC 20210

102 TELEVISION

MS ESTELLLE PARSLEY

WVDW-TV

CILANNEL 12

PO DRAWER 1212

AUGUSTA GA 30903 
102 TELEVISION

DIRECTOR

PROGRAM OPERATIONS

WRLK-TV

SCETV

2712 MULWOOD AVENUE

COLUMBIA SC 29205

M01 STATE SINGLE POINTS OF CONTACT

ADMINISTRATOR

GEORGLA STATE CZEARINGHOUSE

OFFICE OF PLANNING AND BUDGET

254 WASHINGTON STREET

ATLANTA GA 30334

M01 STATE SINGLE POINT OF CONTACT

MS OMEAGIA BURGESS

GRANT SERVICES

OFFICE OF THE GOVERNOR

EDGAR A BROWN BUILDING

1205 PENDLETON STREET

ROOM 477

COLUMBIA SC 29201 

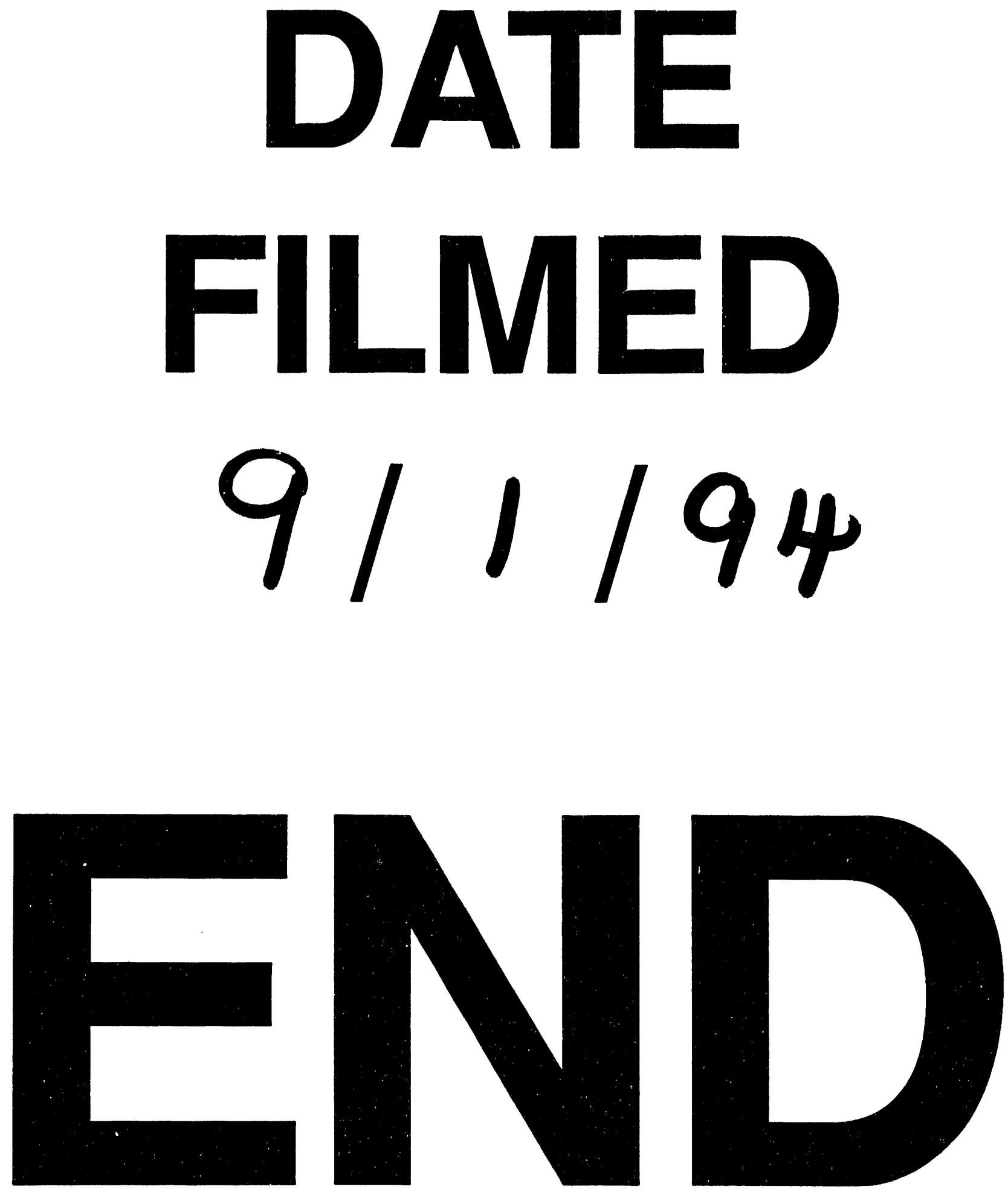
